\title{
PREDOMÍNIO DO ASSÉDIO MORAL NA ADMINISTRAÇÃO PÚBLICA
}

\author{
RECURRENCE OF THE MORAL HARASSMENT IN THE PUBLIC ADMINISTRATION
}

\author{
Roberto Augusto de Carvalho Campos* \\ Ivanira Pancheri**
}

\begin{abstract}
Resumo:
O presente artigo destina-se a refletir sobre o Assédio Moral no Trabalho e seu predomínio na Administração Pública. Pretende-se compreender o fenômeno do Assédio Moral com seus principais contornos e os motivos pelos quais a Administração Pública caracteriza-se por lugar de maior ocorrência do Assédio Moral. Para tanto, faz-se um levantamento bibliográfico, inclusive com pesquisas empíricas sobre fatos paralelos, mas que, fornecem credibilidade às ilações. Examinando a temática, pode-se formular recomendações para combate de problemática mundial tão grave, inclusive estudando o compliance e sua criminalização.
\end{abstract}

Palavras-chave: Assédio Moral. Administração Pública. Política Pública. Compliance. Criminalização.

\begin{abstract}
:
This paper aims to reflect on moral harassment in work places and its recurrence in Public Administration. It is intended to understand the phenomenon of moral harassment with its main borders and the reasons why the Public Administration is characterized as place of greatest occurrence of moral harassment. For that, a bibliographical survey is made, including with empirical researches on parallel facts, which provide credibility to these facts. Examining the subject, one can formulate recommendations to combat such serious world problems, including by studying compliance and criminalization.
\end{abstract}

Keywords: Moral Harassment. Public Administration. Public Policy. Compliance. Criminalization.

\footnotetext{
Possui graduação em Medicina pela Universidade Federal de São Paulo-Escola Paulista de Medicina (1982), graduação em Direito pela Universidade Presbiteriana Mackenzie (1997), mestrado em Otorrinolaringologia e Cirurgia de Cabeça e Pescoço pela Universidade Federal de São Paulo (1995) e doutorado em Medicina pela Universidade Federal de São Paulo (2000). Atualmente é Professor Doutor do Departamento de Direito Penal, Medicina Forense e Criminologia da Faculdade de Direito do Largo de São Francisco - Universidade de São Paulo. Tem experiência na área de Neurocirurgia, Direito Médico e Medicina Legal, atuando principalmente nos seguintes temas: bioética, biodireito, deontologia e otoneurologia.

** Pós-Doutoranda em Direito Penal pela Universidade de São Paulo (2015). Graduada em Direito pela Universidade de São Paulo (1993). Mestrado em Direito Processual Penal pela Universidade de São Paulo (2000). Pós-Graduação lato sensu em Direito Ambiental pela Faculdades Metropolitanas Unidas (2009). Doutorado em Direito Penal pela Universidade de São Paulo (2013). Atualmente é advogada - Procuradoria Geral do Estado de São Paulo. Esteve à frente do Sindicato dos Procuradores do Estado, das Autarquias, das Fundações e das Universidades Públicas do Estado de São Paulo. Participa em bancas examinadoras da Faculdade de Direito da Universidade de São Paulo como Professora Convidada. Autora de artigos e publicações em revistas especializadas na área do Direito. Colunista no Jornal Estado de Direito. Tem experiência na área de Direito, com ênfase em Direito Penal, Processual Penal, Ambiental e Biodireito.
} 
Introdução

O artigo pretende estudar o Assédio Moral na Administração Pública.

Em verdade, objetiva-se alcançar os motivos que propiciam a ocorrência de fenômeno tão devastador num ambiente cujo primado é a legalidade e a moralidade e a eticidade.

Analisado este panorama, deve-se tecer algumas ponderações que podem auxiliar nas reflexões tendentes a combater esta problemática.

De fato, o ato de assediar é antigo. E, tal abjeto comportamento pode ser vislumbrado em diversos meios.

Hodiernamente porém, ainda que em relações particulares, esta violência psicológica é intolerável e pois, traz à luz as danosas consequências tanto para a vítima quanto para outros terceiros prejudicados, inclusive a própria sociedade.

In casu, o Assédio Moral pode surgir no local do trabalho ou em conexão a este labor.

E a expectativa de um saudável ambiente de trabalho é destruída pelo atávico comportamento do assediador.

Note-se contudo que, este perverso assediador insere-se numa cultura organizacional que não apenas permite como igualmente pode estimular suas agressivas condutas.

E, partindo desta premissa, depreende-se que relações de poder em que burocracia, hierarquia e disciplina regem, são mais propícias ao Assédio Moral.

Noutros termos, quanto maior a estratégia de poder, maior o Assédio Moral. Esta equação explica-se, dentre outros, pelo distanciamento humano que obnubila o trato respeitoso.

Para o combate desta epidemia, por óbvio, deve-se principiar por um debate sobre democratização e ética na Administração Pública inclusivo de um aprimoramento da qualidade do serviço público.

Ao lado porém, indispensável um Código de Conduta e sim, um aprofundamento na altercação do manejo do Direito Penal nesta seara.

\section{Assédio Moral. Considerações nucleares}

O vocábulo assédio tem origem controvertida, mas etimólogos acreditam vir do latim absedius, radicado em "sedes", assento, lugar. Creem igualmente vir do latim obsidium, cerco, cilada, consolidado no latim vulgar adsedium, usado em vez de obsidium, do verbo obsidere - pôr-se à frente, cercar, não se afastar da pessoa. Assim, o termo assédio aludia aos cercos militares a cidades e fortalezas. Posteriormente, o termo 
projetou-se, de modo figurado, a situações coloquiais semelhantes. Perceba-se, porém, que há um componente de circundar, sitiar ou bloquear. E tais ideias principiam por traduzir $\mathrm{o}$ ato de assédio. Em verdade, o assédio envolve uma extensa gama de comportamentos de natureza ofensiva. É geralmente entendido como um comportamento que importuna, perturba ou desestabiliza (FERREIRA, 1986).

De maneira idêntica, cinge-se assédio ao latim ad sedere, significando "sentar-se em frente de". Assim, os exércitos fixavam-se em volta das cidades para a rendição. Assediar é “[...] importunar, perseguir com insistência inoportuna [...] quer dizer cerco, limitação, humilhar até quebrar a força ou a vontade de uma pessoa." (MARTINS, 2017).

Enfim, o assédio sempre existiu em suas variadas formas: no âmbito doméstico, na escola, em vizinhanças, com cunho sexual, discriminatório e, por fim, laboral.

Nada obstante tenham conceitos distintos, não necessariamente são assédios morais estanques. $\mathrm{Na}$ verdade, haveria um bem jurídico violado de forma primária (dignidade) e demais lesões secundárias (direito ao trabalho, direito à integridade psíquica e física, honra, liberdade de consciência, liberdade de expressão, intimidade e igualdade) (URRUTIKOETXEA BARRUTIA, 2014).

Diz-se que:

Denominador común de estas situaciones son el amilanamiento de la víctima, que a menudo ni sabe ni puede reaccionar, que tiene miedos atávicos, temores a posibles represalias y a perjuicios de todo tipo, en muchos casos confirmados por posteriores acontecimientos. El acosador actúa como un depredador que por celos, envidia, incompetencia o por pura maldad infringe un sufrimiento encaminado a desplazar y cosificar a otro ser humano. (MARTÍNEZ GONZÁLEZ, 2011, p. 11).

O problema maior, parece-nos, no campo penal, uma infinidade de tipos de acosso, atomizados pela codificação, num aumento do catálogo dos delitos, olvidando-se que se trata de um único fenômeno, perdendo, contraditoriamente, o respeito e relevância de tal conduta (MARTÍNEZ GONZÁLEZ, 2011).

Vale a observação:

En más, las diversas tutelas diferenciadoras que pudieran existir al respecto de cada una de estas tipologías de acoso, se van a tratar de integrar en un tratamiento conjunto del acoso. En un único tratamiento. Porque eso es lo que parece importante. Que la víctima de cualquier agresión de estas características se vea efectivamente tutelada por el ordenamiento jurídico con independencia del motivo o 
razón por el cual se ve agredida. (FABREGAT MONFORT, 2012, p. 19).

\section{Assédio Moral no Trabalho}

Quanto ao Assédio Moral Laboral, objeto deste estudo, a Organização Internacional do Trabalho (OIT, 2000), em conjunto com a Organização Mundial de Saúde (OIT e OMS, 2000), revelou que as expectativas até 2020 são muito pessimistas. O sofrimento no trabalho com danos psíquicos, inclusive decorrentes do Assédio Moral, terá predominância. Salientam que até $20 \%$ dos casos chegam a extremos fatais, com cometimento de suicídio, e até $40 \%$ de aposentadorias antecipadas são causadas pelo Assédio Moral.

Partindo do exposto, o Assédio Moral no Trabalho perfaz-se como uma violência psicológica laboral a partir de comportamentos agressivos exercidos geralmente de maneira constante, comprometendo a qualidade de vida da vítima, acarretando mazelas psíquico-emocionais, físicas e prejuízos outros que atingem, por reflexo, a sociedade.

No mais, observe:

Terminológicamente, el OVAMT (Observatorio Vasco de Acoso Moral en el Trabajo) señala que el 'mobbing' 'es en realidad un neologismo que no existe en la lengua inglesa, en las que el termino ordinario para designar el tipo de conductas que vamos a tratar es el de 'bully' o 'bullying', y que fue en su día inventado por un psicólogo alemán afincado en Suecia, Heinz Leymann, partiendo del verbo inglés 'to mob' cuyo significado puede equivaler a asediar, hostigar o acosar. El término 'bullying' en lengua inglesa se refiere a una conducta prepotente, arbitraria y tiránica y en Gran Bretaña se distingue entre 'corporate bullying' que es el ejecutado por el empresario o su representante frente a un trabajador o trabajadores, el 'client bullying' que se refiere el ejecutado por las y los clientes o usuarios del servicio frente a la o el trabajador, el 'serial bullying' llevado a cabo por todas y todos los compañeros de trabajo o 'gang bullying' cuando lo es por un grupo de personas. También se puede emplear la palabra 'bossing' cuando se refiere a las acciones desarrolladas por la misma empresa (Sentencia del Tribunal Superior de Justicia de Valencia de 25 de septiembre de 2001). (LAFONT NICUESA, 2008, p. 31).

Ainda, no caso do mobbing:

En inglés, el sustantivo mob significa algo así como 'gentuza o chusma', muchedumbre, manada, jauría, turba o plebe' y pandilla, cuadrilla o peña; y el verbo 
to mob puede traducirse como 'arremeter o lanzarse contra alguien, injuriar groseramente', así como 'regañar, atacar, maltratar o asediar'. Mob, con mayúscula, por su parte, significa 'mafia'. (MOLERO HERMOSILLA, 2010, p. 45).

Conceitua Leymann (1986) Assédio Moral resumidamente como um terror psicológico na vida profissional dirigido de forma sistemática por uma pessoa em face da vítima, acarretando miséria psíquica, psicossomática e social.

Além disso,

Heinz Leymann, psicólogo alemão radicado na Suécia, apropria-se do termo do etólogo austríaco e Prêmio Nobel de Medicina em 1973 Konrad Lorenz (1903-1989) que descreve o assédio 'como sendo o ataque de uma coalizão de membros fracos da mesma espécie contra outro indivíduo mais forte do que eles'. (PIÑUEL Y ZABALA, 2003, p. 52$53)$.

Aliás, veja-se a situação narrada por Francisco Javier Abajo Olivares:

[...] el hombre es ante todo un animal social y compara el comportamiento de los seres humanos dentro de la materialización de este acoso, con el de las ratas, y explica que éstas operan como clan y, ante la presencia de algún animal diferente (no perteneciente al clan), que es reconocido por su olor, el clan de ratas reacciona a través de una alerta o señal, atacando sin piedad al intruso, que a menudo no se defiende por quedar paralizado de terror. (OLIVARES, 2004 apud BABUGIA, 2015, p. 41).

Destarte, Leymann (1986) compreendia o Assédio Moral como um terror psicológico que ocorria no local de trabalho, sistematicamente durante prolongado espaço de tempo cuja consequência tinha-se no abandono laboral e, como outra consequência, a enfermidade. E, constitui-se em uma das experiências mais devastadoras porque o indivíduo é objeto de acosso por parte do próprio grupo social.

Não é casual que os estudos sobre o tema iniciaram-se na Suécia (mais especificamente em 1982 quando se pensa pela primeira em terror psicológico), porque o fenômeno é próprio, sobretudo, de países desenvolvidos, afinal quanto menor a possibilidade de violência direta, maior a possibilidade de Assédio Moral Laboral (MOLERO HERMOSILLA, 2010). Não se tolerando mais a violência pura, substitui-se por uma sutil agressão: "Un tipo de violencia difícilmente acreditable ante un tribunal de justicia, pero que preside las reuniones, los comités, las reuniones de equipos, las negociaciones y hasta las charlas de media mañana ante una máquina de café”. (PIÑUEL Y ZABALA, 2004 apud MOLERO HERMOSILLA, 2010, p. 28). E ainda que 
lá se iniciaram, não repele o triste número de $15 \%$ dos suicídios decorrentes do Assédio Laboral (BABUGIA, 2015, p. 38).

O Assédio Moral no Trabalho teve, entretanto, seu período de maior estudo por volta de 2002, entrando na década seguinte, já em virtude da crise mundial - recessão e desemprego maciço - em declínio, ao menos na dogmática espanhola, num contrassenso eis que, em meio à grave crise, mais relevante é a dignidade do trabalhador (URRUTIKOETXEA BARRUTIA, 2014).

Aliás, esta equação: crise econômica e aumento do Assédio Laboral fora mui bem diagnosticada também pelos Tribunais Argentinos. Veja-se:

[...] No habrá de permitirse que las ya frágiles y precarias condiciones laborales en que desempeñan miles de individuos en razón del elevado nivel de desocupación que se consiga en las estadísticas oficiales se vean agravadas por las conductas asumidas por empleadores o superiores jerárquicos, quienes munidos de un rol o posición dominante, dada la situación actual del mercado laboral, menoscaban, avasallan el derecho de intimidad del dependiente, zona reservada exclusivamente a la incumbencia de éste, que no puede ser atravesada por esta dominancia que hoy día conllevan las relaciones de trabajo. (Cámara en lo Civil, Sala A, exp. 110479/96, 'P., M. c/Cia. de Servicios Hoteleros S.A. s/daños y perjuicios', del 5/6/01).

Reflete, inclusive, estatística preocupante: 4\% dos trabalhadores argentinos já foram vítimas de violência física, 2\% de Assédio Sexual e $8 \%$ de Assédio Moral (BABUGIA, 2015, p. 37).

Não há linha tênue entre o que é Assédio Moral e aquilo que não se constitui como Assédio Moral. As condutas de Assédio Moral consistem em trato vexatório com abuso de autoridade. É o "ningunear", menosprezar, desconsiderar, tratar com indiferença. Admoestações sem desqualificação, conflitos, exercícios irregulares de poder de mando, ainda que possam ser tidos como infrações de outra natureza, não se perfazem em Assédio Moral (GIMENO NAVARRO, 2011, p. 43).

$\mathrm{O}$ quadro atual refere-se ao Assédio Moral como uma conduta objetiva percebida como ataque, em ambiente laboral, continuamente, cuja finalidade, e não mera consequência, é a autoeliminação laboral e cuja enfermidade é prova antes de mais nada.

Ademais, há manobras conceituais: limitação de comunicação e contato social; desprestígio e descrédito da capacidade laboral e pessoal; comprometimento da saúde psíquica. Do impedimento da competência, com negação de contato, passando por injúrias e calúnias da vida pessoal, ameaças e ataques físicos chegando-se até a extremos como roubos e danos contra bens materiais, pessoais ou mesmo instrumentos laborais da vítima (GIMENO NAVARRO, 2011). 
O tema é de tamanha envergadura que mobiliza a comunidade europeia. Aliás, estima-se atualmente que $9 \%$ da população ativa europeia já tenha sofrido Assédio Moral (BABUGIA, 2015).

Enfim, o Assédio Moral no Trabalho consiste em todo e qualquer procedimento injusto, ilegal, imoral e antiético manifestando-se, sobretudo, por condutas, comportamentos, palavras ou gestos, que possam trazer dano à dignidade ou à integridade física e/ou psíquica de uma pessoa, pôr em perigo seu emprego ou degradar o ambiente laboral. São múltiplas atitudes de agressão que menosprezam, intimidam, discriminam, ridicularizam ou punem, normalmente reiteradas, durante o horário de trabalho e no exercício de suas funções, práticas essas que lesam a dignidade do indivíduo e originam sofrimento psíquico e físico, com outras consequências multifacetárias. Atente:

En segundo lugar, el AML (acoso moral laboral) integra
una diversidad de conductas, cuya valoración debe ser
global y no aislada. Algunas de ellas singularmente
consideradas pueden parecer neutras (por ejemplo, la
supervisión constante e individualizada de la prestación del
trabajador, con rectificaciones continuas sobre la labor de
éste por el superior jerárquico, que es algo perfectamente
legítimo en el ejercicio de las facultades directivas), otras
podrán ser consideradas reprochables éticamente, aunque
insuficientes por sí mismas para merecer un reproche
jurídico como conductas degradantes y humillantes
(ofensas verbales, groserías; propagación de maledicencias;
humillaciones en público), otras finalmente por sí mismas
son una manifestación de actuaciones ilícitas, abusivas
o discriminatorias (actuaciones todas sancionables
nominatim). (NAVARRO NIETO, 2007, p. 33-34).

De outro modo, a Organização Internacional do Trabalho (OIT, 2002) enumerou manifestações de Assédio Moral - medidas destinadas a excluir o assediado, ataques ao comportamento pessoal e profissional, rumores e ridicularização, controle desmedido e inapropriado do rendimento - elegendo o Assédio Moral como violência psicológica que afronta seus princípios institucionais de busca de Justiça Social e Respeito aos Direitos Humanos e a Dignidade da Pessoa Humana.

O Assédio Moral como pressão laboral tendenciosa e humilhante contra a pessoa desestabiliza-a, conduzindo ao seu isolamento dos demais membros do grupo, de novo, com graves e diversificadas repercussões e, no limite, força-a a afastar-se de alguma maneira daquele ambiente abusivo. Num contexto de violência moral sutil, mas autoritária, há dificuldades para nomear aquela situação como de Assédio Moral e, quando denunciada, é prontamente negada pelos responsáveis porque demonstra, quando menos, perda de mandamento ético e falha na gestão. 
Uma das maiores especialistas mundiais no tema, a psiquiatra Marie-France Hirigoyen estuda o que classifica de violência perversa como qualquer manifestação abusiva, com condutas hostis, mas muitas vezes de aparência inofensiva, exercida entre companheiros de trabalho, que atenta contra a personalidade, dignidade, saúde física e psíquica, podendo por em perigo o emprego e degradar o ambiente de trabalho, além de outros resultados desastrosos de difícil demonstração, sem o intuito ético de melhorar o serviço mas desfazer-se da pessoa (2008):

Toda e qualquer conduta abusiva manifestando-se, sobretudo por comportamentos, palavras, atos, gestos, escritos que possam trazer dano à personalidade, à dignidade ou à integridade física ou psíquica de uma pessoa, por em perigo seu emprego ou degradar o ambiente de trabalho. (HIRIGOYEN, 2002, p. 18).

Excelente conceituação para o Assédio Moral tem-se na lição da magistrada trabalhista Sonia A. C. Mascaro Nascimento:

A doutrina pátria define o assédio como uma conduta abusiva, de natureza psicológica, que atenta contra a dignidade psíquica, de forma repetitiva e prolongada, e que expõe o trabalhador a situações humilhantes e constrangedoras, capazes de causar ofensa à personalidade, à dignidade ou à integridade psíquica, e que tem por efeito excluir o empregado de sua função ou deteriorar o ambiente de trabalho. (NASCIMENTO, 2011, p. 14).

Está-se diante de uma:

Presión que se ejerza y sea sentida por la víctima, exigiendo un comportamiento severo con peso específico propio, pudiendo ser explícita (mediante palabras despectivas, miradas, risas, etc.) o implícita (hacer el vacío a la víctima); Laboral [...] 'porque fuera del mismo, la persona goza de mayor libertad y la capacidad de supervisión de la empresa es prácticamente nula o disminuye drásticamente'.

Tendencioso [...] y, como tal, el Juez la apreciará ponderando la totalidad de los indicios probatorios que se le presenten. (PORTUGUÉS JIMÉNEZ, 2011, p. 15).

Assédio Moral é converter a vida laboral do assediado em um inferno (GONZÁLEZ NAVARRO, 2009, p. 131). Tem-se no assediador, indivíduo perverso, que desumaniza o outro. Depreende-se no comportamento do assediador uma personalidade mórbida, seja ela de traços psicopáticos, narcisistas ou paranoides (PIÑUEL Y ZABALA, 2003).

Dependendo do especialista em voga, são tidos ou como perversos narcisistas para Hirigoyen; psicopatas organizacionais para Zabala, "Hannibal Lecter 
organizacional" para Abajo Olivares ou ainda simplesmente meros indivíduos medíocres para González de Rivera (BABUGIA, 2015, p. 74 e 134).

Independente da nomenclatura, tem-se que a conduta do assediador obedece ao seu intento de disfarçar suas próprias inapetências e, assim:

Esse medo, essa insegurança são habitualmente determinados pela própria consciência de mediocridade, que é posta em evidência, muito amiúde de maneira inconsciente, pela conduta profissional, ética e respeitosa da pessoa que depois vem a ser selecionada como objetivo. (PIÑUEL Y ZABALA, 2003, p. 129).

$\mathrm{O}$ assediador, com seu mediocrismo percebe a vítima como objeto que dificulta sua satisfação pessoal e profissional. Assedia moralmente e sabe que está agredindo, por sadismo, narcisismo ou inveja, tanto que oculta e dissimula sua prática, mas se mostra como autoridade para punir o outro. Se descoberto em seu ataque, tenta intimidar, negociar ou passar-se por vítima. Atente:

A juicio de los expertos, los factores que intervienen en el acoso psicológico son: por parte do acosador: mediocridad, envidia, afán controlador; por parte del acosado: autenticidad, inocencia, dependencia afectiva; por el entorno: aislamiento, cohesión, improductividad. (MARTÍNEZ GONZÁLEZ, 2011, p. 68).

O assediador busca erros ínfimos, antigos, sequer relatados para justificar medidas disciplinares, desviando, assim, a atenção do real móvel de suas diatribes: antipatia, ciúme, inveja e complexos (PIÑUEL Y ZABALA, 2003).

Emprega perversamente a linguagem para convencer a todos e à própria vítima de que ela é uma má pessoa. Com um discurso carregado de boas intenções, humilha, injuria, difama, mente e insinua, sem um frontal ataque, impedindo a defesa da vítima que progressivamente se angustia. Aparece a dicotomia entre bons e maus. Assim, controla sua imagem pública e engana a todos. Seduz porque necessita de público para afastar sua autoimagem repulsiva: “Quem poderia acreditar que uma pessoa tão adorável e encantadora seja um assediador em série?” (PIÑUEL Y ZABALA, 2003, p. 150). Manipuladores, podem chegar a acumular várias vítimas, umas após as outras, os chamados “cadáveres no armário" (PIÑUEL Y ZABALA, 2003, p. 129), personificando a figura do asesino moral en serie (BABUGIA, 2015, p. 68).

Cuida-se afinal, do cruel exercício: "para que aprenda quem manda" (LAFONT NICUESA, 2008, p. 33).

Um parênteses: Assédio Laboral diz respeito ao trabalho. Assédio Psicológico diz respeito ao conceito: perseguir com empenho, submeter sem repouso a pequenos ataques repetidos. Assédio Moral: é expressão postulada pela psiquiatra e 
vitimóloga francesa Marie-France Hirigoyen. Cogita-se ainda, falar-se Assédio Imoral (MOLERO HERMOSILLA, 2010, p. 50).

Interessantíssima posição vale ser transcrita neste ínterim, quando se está diante da construção de um conceito jurídico de Assédio Moral no Trabalho (afastado de conceitos desenvolvidos por médicos, psicólogos e sociólogos):

[...] debemos reelaborar jurídicamente el concepto en base a las notas definidoras de quién hostiga, qué conductas hace (conductas hostiles donde la reiteración deberá de tenerse en cuenta), qué bienes jurídicos se lesionan (identificación del bien jurídico objeto de protección) y dónde se realizan (la conexión con el trabajo); otras preguntas como por qué o para qué, no nos parecen imprescindibles en la configuración legal del acoso. (URRUTIKOETXEA BARRUTIA, 2014, p. 68).

Noutros termos, está-se a discutir a relevância dos demais elementos usualmente definitórios: finalidade específica ou autoexpulsão do trabalhador, dano lesivo à saúde e mesmo, reiteração.

No primeiro caso, mister não confundir a consequência - abandono - com a finalidade. O emprego de um fim específico resulta extremamente restritivo, aproximandose da prova diabólica. Isto, entretanto, igualmente não se imiscui com intenção ou intencionalidade a partir de dados objetivos apurados. Um fim concreto e malicioso deve servir para graduar a responsabilidade (URRUTIKOETXEA BARRUTIA, 2014).

Quanto ao dano lesivo à saúde, o Assédio Moral como conduta agressiva a outros direitos do assediado deve ser coibida antes que deteriore a saúde da vítima, cujo resultado depende de fatores absolutamente pessoais (URRUTIKOETXEA BARRUTIA, 2014).

Por epílogo, no que concerne à reiteração, principalmente ao considerar-se que uma só conduta pode produzir um estrago continuado para o trabalhador, tem-se:

Tanto en la jurisdicción penal como en la militar existe jurisprudencia en el sentido de considerar que una sola conducta puede configurar un trato degradante [STS (penal) de 22 de enero de 2005 y STS (militar) de 20 de septiembre de 2002]. La duración y persistencia de las conductas no son rasgos inherentes al tipo sino formas de evidenciar la gravedad de las conductas agresivas. (URRUTIKOETXEA BARRUTIA, 2014, p. 95-96).

Cogente ademais, ressaltar que o Assédio Moral Laboral tem como espaço/ tempo quaisquer relações interpessoais trabalhistas, cujo conteúdo não se embaralha com mero vínculo contratual (URRUTIKOETXEA BARRUTIA, 2014). 
Em verdade, o Assédio Moral configura um marco para o ordenamento jurídico em geral à medida que ostenta natureza insidiosa, porém, prescinde ser reconhecido para a tutela dos direitos fundamentais do trabalhador (NAVARRO NIETO, 2007).

O reconhecimento do perigo do Assédio Moral é consequência da positiva evolução da ideia de dignidade de toda pessoa. Aliás, a atual intolerância ao desrespeito dos direitos do indivíduo em quaisquer contextos, assevera avanço para reprimir tal fenômeno, fazendo ruir espaços de silêncio e impunidade permeáveis aos abusivos micropoderes cotidianos. Noutros termos, a noção de cidadania não pode prestar-se apenas como fundamento para a liberdade contratual, devendo inserir-se igualmente no interior da empresa (URRUTIKOETXEA BARRUTIA, 2014).

\section{Predomínio do Assédio Moral na Administração Pública}

O assédio é fenômeno comum na Administração Pública, tornando-a setor de risco desta gravíssima patologia que crava questões profundas sobre desrespeito aos mais elementares princípios regentes da Administração Pública, sobre vícios institucionais e sobre deturpação no que concerne à organização do trabalho e gestão de pessoas. E, ao mesmo tempo, os reflexos mostram-se mais preocupantes ao sopesar-se que se está no âmbito do Estado Democrático de Direito, cujo padrão deveria ser a eticidade na gestão pública pautada pela licitude (MARTÍNEZ GONZÁLEZ, 2011).

Mister pontuar que, a referência ao predomínio do Assédio Moral no Trabalho no âmbito do serviço público impõe definir-se o círculo desta sinistralidade. Noutros termos, está a se mencionar o Assédio Moral que se produz entre e sobre os funcionários públicos, isto é, aqueles servidores submetidos às normas de Direito Administrativo, que não se confundem com empregados que prestam serviços em organismos públicos (CONDE COLMENERO, 2009).

Aliás, este detalhamento suscita outra observação: como justificar a prevalência do Assédio Moral na Administração Pública se o fator mais importante no serviço público é o elemento humano, isto é, como a Administração Pública pode ser um "ninho" de assediadores? (CONDE COLMENERO, 2009, p. 86).

Uma argumentação falaciosa quando se argui sobre a ocorrência do Assédio Moral no Trabalho é estar o assediador coberto pelo manejo do poder diretivo, enleando o trato degradante com o poder de mando.

A autoridade que é conferida ao empregador na gestão da empresa, poder diretivo, não deve ser confundida com autoritarismo. A subordinação do empregado não pode ser manipulada pelo empregador como forma de atingir a dignidade, ou seja, não pode servir de substrato para violar os direitos fundamentais. Nem sempre, entretanto, o empregador age de forma ética. 
Em verdade, o Assédio Moral no Trabalho não se imiscui sequer com um exercício abusivo do poder de direção.

Hodiernamente os direitos fundamentais, incluso dos trabalhadores, são a tônica. Os poderes empresariais devem respeito à dignidade do indivíduo, mormente num momento de novas tecnologias que possibilitam originais e intensas formas de controle (CONDE COLMENERO, 2009).

Veja:

Concretamente los pronunciamientos judiciales proponen tres notas para discriminar cuándo se está ante un acoso y cuándo ante un mero ejercicio ilícito del poder de dirección:

$1^{a}$. En primer lugar, la motivación de la conducta, pues 'si en el primer caso se aprecia intención de perjudicar al trabajador, en el segundo prima el interés - mal entendido - empresarial'; dicho de otro modo 'se exige que no esté primariamente en juego el interés organizativo de la empresa, esto es, que con la conducta lesiva de los derechos de los trabajadores no se busque, si bien por medios inadecuados o desproporcionados, un mayor rendimiento o aprovechamiento de la mano de obra, imponiendo condiciones de trabajo desfavorables para los intereses de los trabajadores pero favorables a los intereses empresariales'.

$2^{\text {a }}$. En segundo lugar, los derechos comprometidos, que si en el caso del acoso son los derechos fundamentales del trabajador - básicamente su dignidad e integridad moral en el supuesto del ejercicio arbitrario del poder empresarial son derechos laborales estrictos.

$3^{\text {a }}$. En tercer lugar, los intereses lesionados, que es la integridad moral del trabajador en el caso del acoso y son los derechos laborales sobre lugar, tiempo, modo y contraprestación del trabajo en el supuesto de ejercicio arbitrario del poder de dirección. (CONDE COLMENERO, 2009, p. 79-80).

Destarte, o que se requer é um saudável ambiente de trabalho derivado de um regular e legítimo exercício do poder diretivo aliado a uma política de prevenção de riscos laborais, garantindo segurança e saúde aliás, como Direito fundamental dos trabalhadores sob pena de responsabilidade do empresário (FABREGAT MONFORT, 2011).

Enfim, é detectada, pois, maior ocorrência do Assédio Moral na Administração Pública e, mormente, em serviços públicos de grande relevância social com modelos elevados de hierarquização, burocratização, responsabilidade e exigência, expondo inclusive ao cidadão que requer qualidade à problemática destes comportamentos 
atentatórios à dignidade do servidor público, ad exemplum: escolas, hospitais, forças armadas e cárceres (MOLERO HERMOSILLA, 2010):

La razón que justifica a mayor predisposición a la ocurrencia del fenómeno en instituciones de tipo público se relaciona con su carácter más intensamente reglamentado, la obsolescencia de buena parte de sus paradigmas de regulación organizativa, el reglamentismo utilizado y una cultura basada en el control, la jerarquía y el poder. (LOPEZ CABARCOS, 2003 apud MOLERO HERMOSILLA, 2010, p. 68).

Existem traços da Administração Pública que poderiam auxiliar na interpretação desta prevalência de assediadores. A excessiva hierarquização, verticalidade e burocratização da organização e gestão públicas, a falta de profissionalismo dos chefes, a arbitrariedade na delimitação de tarefas, a permeabilidade à política, a insuficiente transparência, os entraves jurídicos para o tratamento adequado do Assédio Moral, inclusive nas singularidades da via administrativa primeira que retarda a imediata judicialização e divulgação externa, a ausência de mecanismos de solução, a falta da negociação coletiva no tratamento de matérias relativas aos direitos fundamentais, o emprego abusivo por parte do assediador do poder disciplinar punitivo são apenas algumas peculiaridades que contribuem para a expansão do Assédio Moral na Administração Pública (CONDE COLMENERO, 2009). Noutros termos:

Os ambientes fechados ou burocratizados, típicos das administrações públicas, nos quais predomina a tendência de que tudo esteja preestabelecido e regulamentado, e nos quais existem poucas alternativas, pioram o prognóstico do assédio psicológico no trabalho. (PIÑUEL Y ZABALA, 2003, p. 268).

A gestão pública propicia a prática do Assédio Moral, mormente pela grande discricionariedade, por perseguição em face de posições políticas, pela atual fácil mobilidade e transferência de indivíduos a bem do serviço público. Ademais, os despreparados chefes, alçados a posto de comando por laços de amizade, nepotismo ou pertencimento ao grupo de poder de plantão, sustentam-se facilmente naquelas mesmas relações que os colocaram no poder e, diante deste seguro respaldo e intocabilidade, compensam suas inegáveis inaptidões... Aliás, por óbvio, a indicação de alguém para chefia não tem o condão de milagrosamente transformar tal indivíduo em capaz condutor de pessoas. E, tendo-se em consideração que o chefe não dispõe sobre o vínculo funcional da vítima, principia o acosso e a humilhação para conseguir livrar-se de outro modo dela (CONDE COLMENERO, 2009). 
Ademais, a equação estabilidade/precariedade no vínculo trabalhista e o Assédio Moral também é tema recorrente e, ao reverso do que se possa inferir, o Assédio Moral é diretamente proporcional à estabilidade no emprego. Quão mais firme a relação laboral, mais difícil de extinguir-se e, porquanto, mais Assédio Moral.

Noutros termos, o caráter estável do emprego público pode induzir o assediador, ante o embaraço de desfazer-se legalmente da vítima, a sobrepujantes comportamentos que provocam o autoabandono daquela outra do local de trabalho, seja por baixa médica, pleito de remoção, renúncia à condição funcional, seja, afinal, pelo suicídio (CONDE COLMENERO, 2009).

A envergadura numérica dos casos de Assédio Moral aqui pode ser justificada igualmente pela enormidade de tamanho que a Administração Pública apresenta como grande empregadora. Perceba-se que o Assédio Moral é uma perigosa combinação de uma organização do trabalho patológica e de comportamentos fulcrados "nas misérias da alma humana" (NAVARRO NIETO, 2007, p. 16).

Neste ínterim, forçoso é anotar que o Assédio Moral no Trabalho é uma conduta antijurídica antes de qualquer outra adjetivação, mesmo partindo de uma personalidade atávica.

O fato da Administração Pública empregar muitos indivíduos, aliás, resta por pulverizar todos os problemas de gestão de recursos humanos e organização. Assim, a descentralização administrativa carrega a falta de chefia especializada e competente, a autonomia exacerbada de poder em determinados órgãos e, principalmente o poder disciplinar, tudo em inegável contrassenso eis que a citada descentralização viria para reduzir a burocracia e aprimorar o serviço público. Assim:

Efectivamente, con el intento de salida del modelo público
excesivamente jerarquizado y centralizado lejos de
eliminarse ciertas patologías y vicios públicos, en algunos
supuestos, no se ha conseguido sino continuar (y trasladar)
la jerarquización y burocratización a la periferia [...].
(CONDE COLMENERO, 2009, p. 107-108).

Importa aqui pontuar que revelar a faceta da má organização do trabalho no Assédio Moral "desindividualiza o risco" e enfatiza a responsabilidade estatal quanto à preservação dos direitos fundamentais (URRUTIKOETXEA BARRUTIA, 2014, p. 313). Noutros termos:

En este sentido el acoso pasa a visualizarse no como algo originado por la propia víctima o fruto de la casualidad o mala suerte sino como resultado de las relaciones sociales y de trabajo; no como un peligro, inevitable e incomprensible, sino como un riesgo en el que se puede y debe intervenir socialmente. (URRUTIKOETXEA BARRUTIA, 2014, p. 313). 
Inclusive, ao afastar este aspecto primordial - má organização do trabalho - a Administração Pública reduziria sua responsabilidade estatal, individualizando e nomeando a violência, furtando-se do seu dever em preservar direitos fundamentais, tanto como obrigação de meios, como obrigação de resultados (URRUTIKOETXEA BARRUTIA, 2014).

O que impera restar evidente é que o Assédio Moral, mais que aspectos materiais do trabalho, hoje é a principal causa de enfermidade profissional, sendo conduta ilícita que interessa não apenas à vítima mas que adoece a própria sociedade.

Neste ínterim, definir Assédio Moral no Trabalho como um risco laboral associado a fatores psicossociais derivado de um fato ilícito que se desenvolveu no marco de uma relação trabalhista concede especial dimensão à vítima, reforçando sua defesa legal e enfatizando a obrigação empresarial/estatal de proteção da saúde física e psíquica do trabalhador, inclusive em sede de Seguridade Social, tratando o Assédio Moral no Trabalho e os padecimentos psicofísicos como patologias de origem profissional, leia-se, acidente de trabalho (CONDE COLMENERO, 2009).

Perceba-se porém, que se está a fazer menção à Seguridade Social, plano normativo alheio àquele regente da Administração Pública, cuja diferença de tratamento é notável, e assim, parece imprescindível para obstar dúvidas e posições refratárias e reducionistas do serviço público como “empresário infrator”, uma expressa previsão legal (CONDE COLMENERO, 2009, p. 165).

A erradicação do assédio no âmbito público insere-se inclusivamente na obrigação geral do Estado de proteção da segurança e saúde dos servidores e/ou empregados, com suas pertinentes consequências legais em hipótese de desobediência e, principalmente num reconhecimento de responsabilidade e autocontrole.

Saliente-se:

En el empleo público, por su parte, las medidas pueden aparecer también, en todos los instrumentos propios de la negociación en ese ámbito (convenios para laborales, acuerdos o pactos para funcionarios) e incluso en instrumentos específicos que también serían, en el fondo, convenios o acuerdos, como los planes de igualdad o preventivos. (FABREGAT MONFORT, 2012, p. 48).

Aliás, pode-se cogitar de uma impossibilidade de contratação com a Administração Pública para aqueles que, sancionados por Assédio Moral conforme a Ley de Contratos de las Administraciones Públicas, em seu artigo 20, na Espanha (URRUTIKOETXEA BARRUTIA, 2014, p. 344).

Em geral, todavia, o que aflora é uma negação geral do Assédio Moral ou, em segunda opção, uma participação ativa ao estigmatizar a vítima. Despidos de qualquer compliance para o combate ao Assédio Moral, inábeis para detectar precocemente e 
resolver o acosso, ignoram os sintomas (absenteísmo em suas diferentes modalidades, problemas disciplinares, etc.), não garantem o direito à confidencial denúncia e à assistência, sequer tentam mediar ou arbitrar esta epidemia e largam a vítima à sua própria sorte nas fases finais do Assédio Moral (NAVARRO NIETO, 2007).

Nesta quadra, tem-se:

En ese entorno adverso a la convivencia, no es infrecuente que la gestión del AMT (ACOSO MORAL DEL TRABAJO) por parte del empresario o de los directivos se aborde dos posiciones igualmente recusables: bien negando la existencia del conflicto, bien participando activamente en el mismo con la finalidad de sumarse a la estigmatización de la persona objeto del acoso. (MARTÍNEZ ABASCAL, 2008, p. 75-76).

E mais uma advertência em relação ao Assédio Moral, que resta por fundar esta irresponsável posição do administrador:

Uno de los principales problemas que se plantea en la tutela frente alAML, está en la aportación de elementos probatorios. La cuestión merece su atención porque los hechos que configuran el acoso moral que un trabajador puede padecer en su puesto de trabajo son muy difíciles de probar por la víctima, dado que las conductas de acoso no son fácilmente externalizadas y suelen presentarse acompañadas de un clima de aislamiento respecto de los propios compañeros, se concretan en actos continuos de hostigamiento que poco a poco van minando la autoestima del trabajador, y que incluso aisladamente pueden ser objetivamente legítimas, de ahí, la necesidad de su valoración global. Todo ellos hace que la delimitación y constatación de tales conductas, su prueba, sea una 'ardua o imposible tarea', y requiera 'una interpretación más adaptada y matizada' de las reglas de acreditación de la prueba. (NAVARRO NIETO, 2007, p. 152-153).

Especialmente na Administração Pública, o assediador parece olvidar que, como servidor público, encontra-se sujeito às regras da moralidade administrativa e, pois, de seu pertinente estatuto. Indiscutivelmente, o assediador viola os deveres de conduta compatível com a moralidade administrativa, da urbanidade e da lealdade à instituição a que serve. Emprego do cargo com desvio de função e manifestações de desapreço são igualmente reprováveis. Além disso, o estatuto impõe os deveres de solidariedade com os companheiros de trabalho e, principalmente, dignificação da função pública.

Aliás, na Administração Pública falar-se-á de desvio de poder ou fraude à lei, isto é, "[...] de aplicación de potestades de las que esté legítimamente investido a fines 
distintos de aquellos para los que la potestad fue creada." (GONZÁLEZ NAVARRO, 2009, p. 158).

Vale trazer à colação o seguinte artigo do Código Penal Espanhol a aplicarse especificamente ao mobbing praticado no cerne da Administração Pública, como forma desviada de poder:

Artículo 175. La autoridad o funcionario público que, abusando de su cargo y fuera de los casos comprendidos en el artículo anterior, atentare contra la integridad moral de una persona será castigado con la pena de prisión de dos a cuatro años si el atentado fuera grave, y de prisión de seis meses a dos años si no lo es. Se impondrá, en todo caso, al autor, además de las penas señaladas, la de inhabilitación especial para empleo o cargo público de dos a cuatro años.

E perceba-se, por exemplo, a grave problemática no serviço público ao pensar-se que na Argentina, não há a figura do Assédio Sexual, salvo no Decreto n. 2.385/93 sobre Acoso Sexual en la Administración Pública Nacional que assim define: "[...] el accionar del funcionario que con motivo o en ejercicio de sus funciones se aprovechare de una relación jerárquica, induciendo a otro a acceder sus requerimientos sexuales, haya o no acceso carnal." (BABUGIA, 2015, p. 56).

Aliás, o regramento maior na Argentina sobre Assédio Laboral dá-se, em realidade, junto ao serviço público, tornando-se marco no Direito Administrativo, a saber: Buenos Aires, Lei n. 13.168; Ciudad de Buenos Aires, n. Lei n. 1.225; Entre Ríos, Lei n. 9.671; Jujuy, Lei n. 5.349; Missiones, Lei n. 4.148; Santa Fé, Lei n. 12.434 e Tucumán, Lei n. 7.232. Especialmente a de Santa Fé prevê um sistema de proteção das vítimas e das testemunhas ou para qualquer indivíduo que denuncie o Assédio Laboral (BABUGIA, 2015, p. 95).

No Brasil, o Assédio Moral pode configurar o abuso de autoridade previsto na Lei n. 4.898/65, que sujeita o agente público federal, estadual ou municipal à tríplice responsabilidade civil, administrativa e penal. Para os efeitos desta lei, considera-se autoridade todo aquele que exerce cargo, emprego ou função pública, de natureza civil ou militar, ainda que transitoriamente e sem remuneração. As penas por abuso de autoridade vão desde a advertência administrativa até a demissão, e no processo penal escalonam-se em multa, detenção, perda do cargo e inabilitação para a função pública, aplicadas isolada ou cumulativamente.

Assim, abusos de autoridade relativos à liberdade individual, à inviolabilidade do domicílio e da correspondência e aos direitos de locomoção, crença, consciência, voto e reunião bem como os concernentes à incolumidade física do indivíduo, aí consubstanciados os delitos de vias de fato e lesão corporal, são intoleráveis exemplos de práticas do assediador. 
Perceba-se que os procedimentos da Lei do Abuso de Autoridade são autônomos em relação às outras imputações de responsabilidade civil e administrativa da própria Administração e, ainda, penal visto que o legislador deu legitimidade às vítimas para chamarem a juízo diretamente os seus ofensores.

Por final, em sendo o assediador servidor público da União, do Estado ou do Município, o próprio Estado pode ser responsabilizado pelos danos materiais e morais sofridos pela vítima, porque possui responsabilidade objetiva, independe de prova de sua culpa. E, comprovados fato e dano, cabe ao Estado indenizar a vítima, podendo, entretanto, processar o assediador, visando à reparação dos prejuízos que sofrer em ação regressiva.

No que concerne à legislação em âmbito administrativo, poder-se-á fazer referência, por exemplo, ao Estado de São Paulo no qual o Assédio Moral é, em teoria, atitude proibida no funcionalismo público da Administração direta, indireta, autarquias e fundações públicas, podendo penalizar o assediador até com demissão do cargo. Veja o regramento contido na Lei n. 12.250, de 9 de Fevereiro de 2006:

Artigo $2^{\circ}$ - Considera-se assédio moral para os fins da presente lei, toda ação, gesto ou palavra, praticada de forma repetitiva por agente, servidor, empregado, ou qualquer pessoa que, abusando da autoridade que lhe confere suas funções, tenha por objetivo ou efeito atingir a auto-estima e a autodeterminação do servidor, com danos ao ambiente de trabalho, ao serviço prestado ao público e ao próprio usuário, bem como à evolução, à carreira e à estabilidade funcionais do servidor, especialmente:

I - determinando o cumprimento de atribuições estranhas ou de atividades incompatíveis com o cargo que ocupa, ou em condições e prazos inexeqüíveis;

II - designando para o exercício de funções triviais o exercente de funções técnicas, especializadas, ou aquelas para as quais, de qualquer forma, exijam treinamento e conhecimento específicos;

III - apropriando-se do crédito de idéias, propostas, projetos ou de qualquer trabalho de outrem.

Parágrafo único - Considera-se também assédio moral as ações, gestos e palavras que impliquem:

1 - em desprezo, ignorância ou humilhação ao servidor, que o isolem de contatos com seus superiores hierárquicos e com outros servidores, sujeitando-o a receber informações, atribuições, tarefas e outras atividades somente através de terceiros; 
2 - na sonegação de informações que sejam necessárias ao desempenho de suas funções ou úteis a sua vida funcional;

3 - na divulgação de rumores e comentários maliciosos, bem como na prática de críticas reiteradas ou na de subestimação de esforços, que atinjam a dignidade do servidor;

4 - na exposição do servidor a efeitos físicos ou mentais adversos, em prejuízo de seu desenvolvimento pessoal e profissional.

E ainda,

Artigo $4^{\circ}$ - O assédio moral praticado pelo agente, servidor, empregado ou qualquer pessoa que exerça função de autoridade nos termos desta lei, é infração grave e sujeitará $\mathrm{o}$ infrator às seguintes penalidades:

I - advertência;

II - suspensão;

III - demissão.

Ademais, a já mencionada lei estadual de São Paulo, Lei n. 12.250, de 9/2/2006, além de definir Assédio Moral (art. $1^{\circ}$ ), oferta medidas preventivas (art. $7^{\circ}$ ) e protege inclusive as testemunhas (art. $5^{\circ}$ ).

Nesta conjuntura, pois, há normas jurídicas do serviço público, como leis estaduais do Rio de Janeiro (Lei n. 3.921, de 23 de Agosto de 2002), Paraíba (Lei Complementar n. 63, de 9 de Julho de 2004) e Rio Grande do Sul (Lei Complementar n. 12.561, de 12 de Julho de 2006), além de projetos de lei em tramitação em outros estados e leis em alguns municípios, sendo Iracemápolis a primeira municipalidade a regrar o Assédio Moral (Lei n. 1.163/2000 e Decreto regulamentador n. 1.134/2001), tendo São Paulo, Natal e Campinas também interessantemente legislado a respeito (nesta ordem, Leis ns. 13.288/2002, 189/2002 e 11.409/2002).

3.1. Assédio Moral e Assédio Sexual das policiais femininas nas instituições de Segurança Pública. Relação poder e assédio

Enfim, não se olvida que hierarquia e disciplina estão presentes em qualquer forma de organização do trabalho, porém, há um recrudescimento desta principiologia na Administração Pública e, especificamente, em contextos policiais (BRASIL. Ministério da Justiça e da Cidadania, 2016), o que interfere no fenômeno do assédio.

Especialmente, a hierarquia e a disciplina despontam postuladas convencionalmente como o alicerce institucional das Forças Armadas no Estatuto dos Militares, na Lei Federal n. 6.880/80. Neste sentido, os parágrafos do versículo 14 definem tais termos: 
$\S 1^{\circ}$. A hierarquia militar é a ordenação da autoridade, em níveis diferentes, dentro da estrutura das Forças Armadas. A ordenação se faz por postos ou graduações; dentro de um mesmo posto ou graduação se faz pela antigüidade no posto ou na graduação. $\mathrm{O}$ respeito à hierarquia é consubstanciado no espírito de acatamento à seqüência de autoridade;

$\S 2^{\circ}$. Disciplina é a rigorosa observância e o acatamento integral das leis, regulamentos, normas e disposições que fundamentam o organismo militar e coordenam seu funcionamento regular e harmônico, traduzindo-se pelo perfeito cumprimento do dever por parte de todos e de cada um dos componentes desse organismo.

Neste sentido, ao verificar-se a cultura organizacional, podem-se inferir implicações na dinâmica funcional e, assim, a presença do assédio nas organizações conectase a uma equação cujos fatores - presença de normas de conduta restritas, configuração de um sistema fechado, distância do poder, características mais predominantemente associadas à masculinidade, excesso de poder combinado aos cargos superiores, carência de regras regulamentadoras que subsidiem a gestão dos subordinados, etc., determinam a maior ou menor suscetibilidade a situações de assédio (BRASIL. Ministério da Justiça e da Cidadania, 2016).

E tal quadro, caminha para uma exacerbação à medida que a burocratização bem assim se eleva. Destarte, tem-se como ilação no extremo contexto das Corporações Militares:

Diante do exposto, analisa-se que os valores de hierarquia e disciplina da cultura organizacional da polícia militar influenciam configurações de poder que colocam o subordinado em uma posição de alta vulnerabilidade e tensão. Ainda que esta posição já tenha sido comprovada por estudos da literatura nacional e internacional como potencialmente adoecedora, são conhecidas poucas tentativas de transformação desta realidade. (BRASIL. Ministério da Justiça e da Cidadania, 2016, p. 35).

In casu, a percepção do fenômeno do Assédio Moral e Sexual das mulheres atuantes em Segurança Pública perpassa ainda, por um histórico estudo institucional.

O ingresso de mulheres nas Instituições de Segurança Pública no Brasil é recente. Tem-se como marco a criação de um Corpo Feminino na Guarda Civil do Estado de São Paulo, em 1955. Após, nos anos 1970, esse grupo foi integrado à recém-formada Polícia Militar do Estado de São Paulo. Na mesma época, Polícias Militares de outras unidades da federação principiaram a incorporar mulheres aos seus quadros de pessoal, de maneira unificada aos quadros masculinos ou não. A ampliação dar-se-á principalmente com a promulgação da Constituição Federal, em face da introdução dos princípios de 
respeito aos direitos humanos em um modelo de segurança cidadã. Os cargos mais altos de instituições de segurança pública em diversos estados brasileiros, contudo, somente principiaram a ser acessados pelas mulheres a partir da primeira década do século XXI (BRASIL. Secretaria Nacional de Segurança Pública, 2013).

A nova abordagem objetivou a humanização das corporações policiais, intencionando a melhora da imagem da polícia, a aproximação com a população, principalmente da população vulnerável - mulheres, crianças, idosos, etc. Não se desconhece que a abertura das corporações às mulheres cooperou para liberar os homens das atividades administrativas, autorizando que atuassem nas linhas de frente, ocupando os postos mais altos da hierarquia e participando de atos de bravura na luta à criminalidade (BRASIL. Secretaria Nacional de Segurança Pública, 2013).

Em realidade, em que pese a entrada de mulheres nas instituições de Segurança Pública, não houve concomitante política institucional a proceder o reconhecimento da contribuição profissional e técnica destas, o que redundaria, inclusive, num diverso funcionamento social das instituições, a saber, mais humanitário.

A ausência de transversalização de gênero nas instituições de Segurança Pública é notada desde uma perspectiva material, que despreza a aquisição de equipamentos de proteção individual ergonomicamente adaptado ao uso pelas mulheres, que desatende a importância de creches e áreas para amamentação ou instalações adaptadas para o uso feminino - como alojamentos e banheiros - até a tolerância às piadinhas e graças, ao costumeiro exercício de função secretarial pelas policiais femininas, culminando com o assédio (BRASIL. Secretaria Nacional de Segurança Pública, 2013).

Quanto ao assédio, observe o que narram as mulheres entrevistadas:

Para as entrevistadas, o assédio moral é grave e está presente o tempo todo, afetando homens e mulheres indistintamente. Para a maior parte das entrevistadas, as instituições de segurança pública não oferecem qualquer tipo de apoio para vítimas de assédio sexual e/ou moral, não oferecem canais de denúncia que sejam confiáveis e que não resultem em novas punições e constrangimentos para as vítimas. De acordo com algumas entrevistadas, o apoio da instituição depende da postura profissional de um ou outro chefe que, mesmo sendo homem, pode se sensibilizar com a situação e tentar ajudar. No entanto, mencionaram que a saída será sempre pela remoção da pessoa que é assediada para outro departamento/batalhão/setor, nunca pela denúncia daquele que assedia. Inseridas neste cenário institucional e socializadas na lógica machista, as entrevistadas afirmam que grande parte do problema pode ser resolvido se as mulheres adotarem a 'postura adequada'. Manter-se séria, trocar a gentileza pela sisudez, manter-se em permanente vigilância e autoexigência para a 'perfeita' execução de 
tarefas, mesmo as mais simples e cotidianas, são algumas das fórmulas de que lançam mão para mostrar aos colegas que estão ali como profissionais e esperam este reconhecimento. (BRASIL. Secretaria Nacional de Segurança Pública, 2013, p. 36).

Novamente se percebe que no extremo da hierarquia e disciplina, o assédio é mais presente. Noutros termos, o cenário que envolve mulheres policiais é distinto - policiais civis, peritas, militares e bombeiras militares - mas, quando as relações hierárquicas são mais densas, maiores os experimentos de humilhações, desrespeito, discriminação e assédio, ilustrando uma diferença significativa na experiência de profissionais de instituições militarizadas, que mais relataram ter sofrido situações de discriminação, humilhações e Assédio Moral e Sexual protagonizadas por colegas de trabalho e superiores hierárquicos:

Entre as peritas criminais/policiais encontra-se o maior percentual de profissionais que declararam nunca terem se sentido discriminadas, humilhadas, ou desrespeitadas em seu ambiente de trabalho, pelo fato de serem mulheres. São $32,7 \%$ daquelas que responderam a pesquisa. [...] Entre Bombeiras Militares, 14,6\% declararam que nunca se sentiram humilhadas ou discriminadas por serem mulheres. Dentre as policiais militares, $11,5 \%$ declararam que nunca se sentiram humilhadas, discriminadas em seu ambiente de trabalho ou sofreram constrangimentos e assédios de natureza sexual - o menor percentual nessa categoria. (BRASIL. Secretaria Nacional de Segurança Pública, 2013, p. 83-84).

Ademais, nesta dinâmica, a preponderância do Assédio Moral em relação ao Sexual entremostra-se como prova contundente da conexão entre poder e assédio, que inclusive supera as relações de gênero. Atente-se:

Situações de assédio sexual (4,2\%), discriminação racial $(1,2 \%)$ e discriminação por orientação sexual $(1,0 \%)$ foram menos mencionadas. Contudo, esses baixos percentuais não significam que episódios dessa natureza não tenham ocorrido com mulheres que optaram por não compartilhar suas experiências. Como mencionado anteriormente, muitas mulheres comentaram sobre seu temor em serem identificadas, outras declararam que preferiam não falar sobre a situação que ainda lhes causava dor e sofrimento. Por fim, há também vergonha e mesmo dificuldade em reconhecer determinadas situações como violação de direitos. (BRASIL. Secretaria Nacional de Segurança Pública, 2013, p. 83).

E, ainda: 


\begin{abstract}
Algumas entrevistadas mencionaram também episódios de constrangimento - como ser espionada durante o banho, ou ouvir cantadas e receber convites para sair, mas apenas um pequeno número delas falou sobre episódios mais graves de assédio sexual - como experiência pessoal ou vivida por terceiros -, o que ocorreu principalmente nas instituições militares onde a hierarquia contribui para a prática do crime e seu ocultamento. (BRASIL. Secretaria Nacional de Segurança Pública, 2013, p. 35-36).
\end{abstract}

Depreende-se que a importância das relações profundamente hierarquizadas e as tensões advindas da presença feminina nesse ambiente masculino acirram conflitos que afetam as mulheres em suas condições de gênero favorecendo os tratamentos discriminatórios (BRASIL. Secretaria Nacional de Segurança Pública, 2013).

Assim, independente de ser o Assédio Sexual uma exteriorização do desejo de humilhação e domínio, o Assédio Moral, compartilhado entre homens e mulheres, resta por prevalecer numericamente. A pressão do adestramento é tal que, muitas vezes, as próprias mulheres introjetam os preconceitos e assumem características masculinas, esquecendo-se que se cuida de um padrão institucional refratário aos Direitos Humanos, como efeito da sustentação da hierarquia social que outorga a supremacia masculina no trabalho (SOUZA, 2007).

Aliás, não há uma ponderação pelas policiais femininas sobre ser mulher e policial, ainda que reconheçam os obstáculos nas relações de trabalho e o machismo. Comportamentos misóginos não são facilmente perceptíveis em discursos pautados em direito à igualdade (BRASIL. Secretaria Nacional de Segurança Pública, 2013).

Há uma inegável visão machista predominante na corporação na qual os homens, inclusive, têm bloqueio para se sujeitarem às ordens das mulheres que, em verdade, são vistas como aquelas que estão a desobedecer seu papel na sociedade (SOUZA; MINAYO, 2003).

A inexistência de políticas institucionais para transformar tais conjunturas agrava o quadro das vítimas que buscam por soluções individuais, tendo os danos à saúde psíquica e física, ou mesmo resultados extremos como suicídios, vistos como questões particulares e não com o real significado da má configuração de poder (BRASIL. Secretaria Nacional de Segurança Pública, 2013).

Recorde-se especialmente que, na esfera militar, não há um enquadramento exclusivo para o Assédio Moral ou mesmo sexual, podendo porém, ser invocadas outras tipificações referentes a crimes militares, ad exemplum, calúnia, difamação, privação de liberdade, constrangimento ilegal, excessos, inclusive no ato de punir, violência e ofensa aviltante entre outros. 
Enfim, parece olvidar o Estado que a consagração da pessoa e sua dignidade constituem o centro do nosso sistema constitucional baseado no Estado Democrático de Direito. A preservação da dignidade do trabalhador, a proteção contra o Assédio Moral, a adoção de medidas para assegurar a intimidade e o trato respeitoso são de ordinária legalidade.

Além disso:

Proyectado al ámbito del 'mobbing', el concepto de moralidad pública, la situación de acoso moral tolerada por el trabajador aún integrada en su dignidad como capacidad de autodeterminación de la persona vulnera la moralidad pública al herir en un ámbito de transcendencia pública como el puesto de trabajo las convicciones mayoritarias de la sociedad española que exigen que el trabajador sea respetado en el desempeño de su labor y proscriben las conductas acosadoras. (LAFONT NICUESA, 2008, p. 99$100)$.

Importante realçar que o Assédio Moral é atentado contra o trabalhador e, assim, significa ao menos, uma omissão das medidas de segurança do empregador que deveria proteger a saúde física e mental e os direitos fundamentais, independente de quem tenha o provocado (LAFONT NICUESA, 2008). Inclusive, quando se está a falar de Administração Pública e Direito Penal, ao menos no ordenamento espanhol, tem-se a posição de garante enfocada:

La posición de garante es proyectable también en el ámbito de la Administración al concurrir un riesgo que deriva de la actuación de la Administración al servicio del interés general y una específica posición de dominio en el ámbito en el que se produce la conducta que faculta a la Administración a desplegar una conducta eficaz para acabar con tal situación. El principio de jerarquía otorga un marco eficaz de actuación, una posición de dominio sobre la causa del resultado que genera un específico deber de evitar la continuación del delito. (LAFONT NICUESA, 2008, p. 280-281).

Ademais, há indiscutível interpretação pró-direito à saúde do trabalhador na medida em que os poderes públicos devem velar pela seguridade no trabalho (NAVARRO NIETO, 2007) sem olvidar da dignidade do trabalhador.

Porém, o mais nefasto, como dito, é o Estado assumir a posição de assediador. 


\section{Políticas Públicas de combate ao Assédio Moral}

A formulação científica de ações governamentais para realizar melhoras ao trabalhador no que concerne ao Assédio Moral no Trabalho demanda, inúmeras reflexões, “O dicho de otro modo, ninguna 'intranet' solucionará nunca un problema de acoso laboral." (MOLERO HERMOSILLA, 2010, p. 20).

Em primeiro, deve-se apontar a imprescindibilidade de uma proteção integral, abraçando todas as possíveis tutelas do ordenamento jurídico, a saber, trabalhista/ civil, administrativa e penal.

Em segundo, deve-se indicar que a genérica tomada de decisões em regra, beneficia a erradicação do Assédio Moral na Administração Pública, contudo, não se pode olvidar que as peculiaridades do serviço público devem aqui ser respeitadas. Neste sentido, soluções especiais requerem reflexão.

Destarte, diversamente do Direito do Trabalho que não possui nenhuma lei especial (tendo como alternativa, a contenção do Assédio Moral em convenções e acordos coletivos de trabalho), na Administração Pública, muitos entes federativos já legislaram ou estão em vias de promulgação de normativas que preveem a figura do Assédio Moral do Trabalho.

Diante deste dado, conclui-se que, há uma melhor especificação em sede administrativa, alcançando mesmo, em tese, a pena demissória do assediador, em que pese haver também, uma responsabilização comum do Estado, quando do incumprimento do dever de proteção da saúde e vida do servidor, com a consequente tutela civil indenizatória e ressarcitória (inclusive via responsabilidade objetiva).

Por outro lado, no que concerne às medidas preventivas - Código de Conduta - ou repressivas - Criminalização -, há indispensabilidade de um aprofundamento.

E destas será o enfoque, pelo prisma da Administração Pública.

\subsection{Compliance}

No que concerne ao Código de Conduta ou Protocolo sobre Assédio Moral no Trabalho, o questionamento primeiro é sua adequação em sede de funcionalismo público:

Llegado este punto cabe preguntarse si verdaderamente es posible, útil e idónea esta vía de prevención para promover una lucha eficaz contra el acoso moral en las AAPP, es decir, si la elaboración de códigos éticos y de buen gobierno que rijan la actuación administrativa pueden contribuir eficazmente a la prevención y lucha contra las prácticas acosadoras en el empleo público y, en ese caso, de qué 
modo se arbitraría técnica y jurídicamente su regulación.

(CONDE COLMENERO, 2009, p. 133).

De fato, a prevenção é fundamental, retirando da extinção da relação laboral a ignóbil marca de solução para o Assédio Moral.

Aguardar, no plano individual, a agudização do Assédio Moral, pela baixa laboral como prova do fato, é atuar apenas diante da casuística e não obstar sua produção, ou ao menos, detectá-la de maneira inicial, o que neste tema é de fundamental relevância para a vítima, antes de mais nada, uma cidadã do Estado Democrático Social de Direito (inclusive atuando de forma global sobre todos os fatores que causam o Assédio Moral, respondendo afinal à organização) (GIMENO NAVARRO, 2011).

$\mathrm{E}$, in casu, não se pode olvidar que o vínculo laboral quase vitalício reduz a mobilidade profissional da vítima e o escape mais comum à deteriorada situação de assédio (CONDE COLMENERO, 2009).

No mais, esta eticidade de deveres do servidor público coloca o foco no assediador, tentando recordar a este que deve submeter-se à legalidade e pode sofrer consequências disciplinares. Assim:

1. En ellos se contiene un basamento ético-regulador del cumplimiento de los deberes y obligaciones del empleado público. El empleado público debe desempeñar sus funciones guiado por una meta última, amplia y general acorde a la naturaleza pública de la Administración y al sometimiento a la legalidad que rige especialmente para los poderes públicos [...].

2. La finalidad del Código de Conducta es pedagógica y orientadora, si bien se vincula directamente al régimen disciplinario puesto que los principios y reglas que lo constituyen informarán la interpretación y aplicación de ese régimen. De este modo el Código no tiene sólo carácter programático sino que, irremediablemente, adquiere también, eficacia directa sancionadora [...].

3. Su regulación supone una fijación del catálogo de deberes y obligaciones del empleado público y sus límites, en una triple vertiente (con dimensión interna y externa)

a. Hacia el ciudadano

b. Hacia la Administración misma y demás empleados públicos

c. Hacia las necesidades del servicio

4. De su establecimiento se derivan consecuencias disciplinarias y sancionadoras con el fin de poner límites a las conductas lícitas [...]. El régimen administrativo disciplinario regula toda actuación del empleado público y, 
en ese sentido, corrige cualquier conducta ilícita que éste desarrolle en el ejercicio de sus funciones con respecto a los ciudadanos, la Administración y demás servidores públicos - superiores, compañeros o subordinados-. A su vez, tal como se indicó en otro momento de este estudio, el régimen disciplinario incluye la mención expresa al acoso moral y laboral [...] considerándolos como faltas muy graves. (CONDE COLMENERO, 2009, p. 135-136).

Há diretrizes universais a serem inseridas em pautas de negociação coletiva que conduzem a um positivo comprometimento de todos e de cada um. Veja-se:

En el marco de una economía evolucionada y basada en el conocimiento y en la innovación nuestras relaciones laborales deberían ser de calidad, primando la colaboración sobre el simple ejercicio del poder jerárquico, la transparencia sobre el corporativismo, la iniciativa sobre la inercia de los procesos. Sin embargo, no es así. Nos encontramos ante una importante paradoja empresarial: disponiendo de medios, recursos y conocimientos para desarrollar organizaciones saludables estamos creando entornos de trabajo tóxicos. (GIMENO NAVARRO, 2011, p. 25).

Parte-se, em tese, de principais quatro momentos para fixar o Compliance: prevenção proativa, detecção precoce de situações de risco de Assédio Moral, gestão e solução interna do conflito e respostas da organização (GIMENO NAVARRO, 2011).

Assim, da prevenção proativa caminha-se para uma tomada de decisão a partir de denúncias de Assédio Moral e, por fim, deve-se dar uma experiência organizacional. Mais detalhadamente, de início, observar a natureza da atividade, características dos postos de trabalho, perfil dos empregados e, assim, eleger método de avaliação. Depois, firmar código de ética, com sancionamento para condutas de descumprimento. Importante é articular um centro de recepção das denúncias e comissões investigativas. Um calendário sem pressões e um local em que haja estímulo à independência e à responsabilidade com acesso a promoções é fundamental (GIMENO NAVARRO, 2011).

Indubitavelmente, o enfoque preventivo é recomendável. Parte-se de um tratamento preventivo, proativo e integral, com intervenção célere, nos momentos iniciais do Assédio Moral, sem graves danos ainda à vítima e, de princípio, mais facilmente solvidos (FABREGAT MONFORT, 2012).

Aliás, a tendência laboralizadora da Administração Pública aqui oferta um aspecto positivo: introduzir mecanismos de arbitragem prévios ao ius puniendi (lembrando que este, na maioria esmagadora dos casos, em verdade, serve como móvel para punir novamente a vítima, e não para entremostrar a intolerância da Administração Pública aos comportamentos dos assediadores). 
Noutros termos, em que pese restrições funcionais à negociação coletiva e à participação dos sindicatos nas discussões, inúmeros e próprios instrumentos podem ser adicionados aos estatutos gerando tulelas preventivas e repressivas. Observe:

Partiendo del reconocimiento del derecho a la negociación colectiva, representación y participación institucional del que gozan los empleados públicos para la determinación de sus condiciones de trabajo - el cual fue en otros tiempos objeto de controvertida polémica doctrinal actualmente superada -, [...], y de las limitaciones que puedan establecer las particularidades propias de la negociación colectiva funcionarial, lo cierto es que con el impulso de la negociación colectiva en el empleo público se descubre una gama insondable de posibilidades de tratamiento del acoso moral laboral en el ámbito público algunas de las cuales ya se han enunciado por el beneficio reportado, fundamentalmente (aunque no únicamente), respecto a la tutela preventiva (elaboración de protocolos de actuación y difusión de los mismos, fomento de acuerdo de compromiso de respeto a la dignidad de los trabajadores, propuesta de planes sobre detección e identificación de estas conductas, formulación de instrucciones sobre información y puesta en conocimiento de los empleados públicos de las consecuencias del mobbing, creación de comisiones para la investigación del acoso moral, etc). (CONDE COLMENERO, 2009, p. 141).

Depreende-se que, a excessiva burocratização correlacionada à via administrativa-punitiva em sede de Administração Pública não favorece a resolução do Assédio Moral no Trabalho, sendo em verdade, uma segunda vitimização ao assediado.

Há indispensabilidade de fórmulas especiais para romper tal cultura. Assim: desde canais de recebimento de denúncias, mesmo que em anonimato, até sistemas de conciliação, arbitragem e mediação impelem reflexão (CONDE COLMENERO, 2009).

A organização de trabalho tem papel de destaque nos casos de Assédio Moral. Observar este dado é tratar o problema como além de uma questão de violência pontual, isolada. É também, repelir costumeira justificativa de que se está diante de mais uma das violências globalizadas impossíveis de conter.

Inclusive se caminha para uma solução digna e refuta-se aquela outra fácil: “[...] 'eliminar' la parte débil del conflito y respaldar a la fuerte." (GIMENO NAVARRO, 2011, p. 32).

Destarte, considerando-se os agentes envolvidos, a ilação igualmente é no sentido de uma negociação coletiva para obter um entorno livre de qualquer tipo de violência moral. 
E outro ponto importante a destacar é que, cuidando-se de original medida preventiva, a conceituação deve ser instrumentalmente ampla, numa lista aberta que aceita qualquer comportamento mínimo de violência no trabalho. E tal, aliás, condiz com a realidade difusa e inominada do Assédio Moral (GIMENO NAVARRO, 2011).

Assim, poderiam ser nomeados como comportamentos relacionados à violência laboral: além do Assédio Moral propriamente dito, agressão física, abuso humilhante, intimidação e ameaça com promessa de emprego de força física ou mesmo, de poder, afinal, estar-se-ia no seio do compliance (GIMENO NAVARRO, 2011).

Esta previsão faz-se necessária ao pensar-se nas inúmeras violações não classificadas, ad exemplum, o próprio whistleblower pode ser vítima de Assédio Moral no Trabalho:

La relación de este fenómeno con los síndromes de acoso proviene precisamente de la reacción de la entidad que de alguna manera es puesta en tela de juicio, que habitualmente toma represalias contra quien osa sacar a la luz las corruptelas del sistema. (MOLERO HERMOSILLA, 2010, p. 47).

\subsection{Criminalização}

O incremento da altercação sobre o Assédio Moral nos dias atuais finca raízes em dois fenômenos bem demarcados: a publicização das relações privadas e o redimensionamento da pessoa humana. Noutros termos, poder-se-ia concluir que a maior visibilidade do Assédio Moral dê-se, sobretudo, em virtude de sua inaceitabilidade atual, refutando a antiga percepção de comportamentos normais e desejáveis de socialização (a serem sofridos em silêncio), além do óbvio influxo dos direitos fundamentais (URRUTIKOETXEA BARRUTIA, 2009).

Outro ponto interessante é revelar que numa sociedade altamente consumista, as relações laborais impõem maior respeitabilidade, afastando-se do feudalismo industrial, devendo, pois, ser vistas como relações interpessoais e não relações de produtividade (URRUTIKOETXEA BARRUTIA, 2009).

Previamente ao debate sobre um novo tipo penal, não se pode desconsiderar o manejo de crimes já existentes no ordenamento jurídico para coibir o Assédio Moral no Trabalho.

Noutros termos, mesmo ainda não existindo um crime de Assédio Moral, tal comportamento pode perfeitamente enquadrar-se em outros tipos penais à medida que ofender bens jurídicos tutelados pelo Direito Penal. Portanto, recorde-se, pode haver crime contra a honra (injúria, difamação ou mesmo, calúnia), crime de periclitação da vida e da saúde (maus-tratos, por exemplo), crime contra a liberdade individual (constrangimento ilegal, ameaça), supressão de documento público/particular, prevaricação, etc. 
Enfim, quanto à criminalização do Assédio Moral, nada obstante em face de a ultima ratio ser importante às tutelas inibitórias, restitutórias e reparatórias, os bens jurídicos em risco no Assédio Moral ostentam inegável relevância penal: dignidade da pessoa; direito à vida e à integridade física e psíquica; honra; liberdade individual e direitos trabalhistas.

E daí, a resposta para a dissuasão e prevenção está centrada em todas as ordens normativas. Em evidente cautela com o ne bis in idem, o sancionamento pode atingir as esferas administrativas, civis e penais. Inclusive em ordenamentos que preveem a responsabilização penal da pessoa jurídica, a via penal é indicada (URRUTIKOETXEA BARRUTIA, 2009).

Outrossim, tal ilação vai ao encontro da recepção da sociedade do risco pelo Direito Penal, isto é, novos riscos com dificuldade para atribuição de responsabilidade e sentimento geral de insegurança.

Noutros termos,

La raíz de estos nuevos riesgos se encuentra en el tipo de relaciones laborales vigentes, en el clima laboral existente, en las relaciones sociales, y en la cultura organizacional. Estos nuevos riesgos ya no tienen que ver con el qué se hace y con qué se hace; sí no con el con quién se hace y cómo se quiere hacer. Tienen que ver con la relación, la estrategia y el poder. No se trata pues de prevenir las tareas a realizar y los medios con los que las vamos a realizar, sino el ambiente social del trabajo y la cultura de la empresa. (GIMENO NAVARRO, 2011, p. 32).

Importa alertar que, em geral, existem três correntes sobre a criminalização do Assédio Moral no Trabalho. A primeira advoga o emprego do Direito Penal com fulcro em que sem tal campo de proteção, regras de ordem pública restariam sem efeito. A segunda, ao reverso, refuta a intervenção do Direito Penal ao fundar que haveria um prejuízo das relações laborais. E, por terceiro posicionamento, surge corrente intermediária apontando que seria perigoso aos direitos dos trabalhadores não manejar poderoso instrumento (PORTUGUÉS JIMÉNEZ, 2011).

O Assédio Moral no Trabalho como ilícito penal correlaciona-se, em verdade, a uma sociedade que impõe a observância dos direitos fundamentais inclusive nas relações privadas entre os cidadãos.

E há autores que indiscutivelmente entendem o Direito Penal como prioritário para erradicar o Assédio Moral, sendo a intervenção penal primeira e principal solução frente ao Assédio Moral que violenta a integridade moral/dignidade da pessoa humana (LAFONT NICUESA, 2008). 
Em suma, há respeitadas opiniões sobre a necessidade de incriminação do Assédio Moral, inclusive em paralelo ao Assédio Sexual, apontando para o apenamento com maior aplicabilidade do tipo penal. E tal se dá primordialmente no Brasil que, diversamente da Espanha, não ostenta tipos penais muito próximos: "Un nuevo delito daría una respuesta expresa a una convicción social sobre la gravedad de una conducta. El abuso de una posición de superioridad laboral o funcionarial para vejar y humillar a una persona despierta un profundo reproche y alarma social". (LAFONT NICUESA, 2008, p. 428).

Não se pode olvidar da magnitude do assunto, considerando-se os bens jurídicos envolvidos, protegidos na Constituição e em Convenções Internacionais. Assim sendo, a relevância do bem jurídico a ser protegido no Assédio Moral, qual seja, a dignidade da pessoa humana, justificaria a intervenção de todo o arsenal legislativo, inclusive o criminal: "No se nos ocurren bienes de mayor importancia que estos para que intervenga en su protección todo el derecho, también el penal, ya que detrás de ellos se perfila el ciudadano y la persona." (URRUTIKOETXEA BARRUTIA, 2009, p. 20).

E, continua a preleção: "A la vista de la parca respuesta judicial a la criminalización del acoso laboral, quizás una recepción expresa del mismo como modalidad del atentado contra la integridad moral sirva para generar una mayor receptibilidad en la judicatura de esta opción". (URRUTIKOETXEA BARRUTIA, 2009, p. 74).

No mais, reitere-se, o Assédio Moral constitui-se como atos violentos carentes de quaisquer justificativas sejam legais ou sociais, responsáveis por lesão de bens jurídicos de indubitável importância para o indivíduo e para a sociedade. Deste modo, ainda que se constitua de prevalente violência psicológica, hoje tal lesão à pessoa, com traços de dominação, ainda que em relações privadas, é insuportável (URRUTIKOETXEA BARRUTIA, 2009).

Assim:

\begin{abstract}
Ni qué decir tiene que la posición de quien padece mobbing es manifiestamente complicada pues, por un lado, se ven afectados aspectos personales (su dignidad, su salud, su honor...) y, por otro, ve peligrar su relación laboral, normalmente, su principal medio de vida y el de su familia. Es por ello que se hace necesaria la articulación de un sistema efectivo de protección que debe comenzar por la delimitación del concepto de mobbing. (PORTUGUÉS JIMÉNEZ, 2011, p. 12-13).
\end{abstract}

E, neste ínterim, diante das peculiaridades do Assédio Moral na Administração Pública, traz-se à colação o que segue: 


\begin{abstract}
Algunos sectores doctrinales aconsejan vivamente la utilización de la vía penal en la sustanciación de los supuestos de acoso laboral no sólo por razones sustantivas (el ordenamiento penal ofrece una gama importante de tipos delictivos donde encajar el acoso moral laboral y conseguir así el castigo del acosador), sino fundamentalmente por motivos de índole procesal en el sentido de que el proceso penal se adecua suficientemente bien a las particularidades fácticas que presenta el acoso y, además, aporta algunas ventajas procedimentales añadinas que hay que valorar positivamente; pero sobre todo si la tutela penal ha sido considerada a juicio de los especialistas como un cauce satisfactorio se debe, en gran medida, al relativo 'fracaso' de otros órdenes jurisdiccionales en dar respuesta integral, contundente y reparadora a las conductas hostigadoras. En el tratamiento jurídico del acoso en la Administración esta situación es especialmente palpable ya que en este ámbito confluyen numerosos factores negativos: las marcadas deficiencias legales y el retraso de la normativa administrativa en hacerse eco de estas conductas, la escasa sensibilidad reinante en la Administración frente a este fenómeno pese a su notable incidencia en este sector $\mathrm{y}$, finalmente las reticencias de la jurisdicción contenciosoadministrativa para reconocer conductas acosadoras y aplicar la normativa existente en la solución de estas patologías laborales. (CONDE COLMENERO, 2009, p. 264).
\end{abstract}

Acrescenta-se ainda que, o ajuizamento direto em face do assediador (sem o peso da pessoa jurídica/Estado ou de sua posição hierárquica), a credibilidade e importância dadas às suas declarações como vítima no processo penal, a extensão do prazo prescricional, a perícia oficial (e, não tachada de parcial), a intervenção do Ministério Público que inclusive desonera financeiramente a vítima, a possibilidade de depurar-se a responsabilidade civil, etc. são lembrados como positivos para invocar-se a tutela penal (CONDE COLMENERO, 2009).

E mais, trazer luz ao ataque, sob a égide do Direito Penal, é maneira de proteger o assediado, figura débil na relação, como igualmente expor tal chaga ao público, evidenciando a inexistente justificação social (URRUTIKOETXEA BARRUTIA, 2009).

Aliás, esta debilidade na relação empregatícia é absolutamente reconhecida, tanto que existem condições inderrogáveis, porque de ordem pública, ainda que haja respeito à autonomia de vontade (BABUGIA, 2015).

Enfim, no que concerne à criminalização do Assédio Moral no Trabalho e a objetividade jurídica, não se pode olvidar que há certa dificuldade em precisar absolutamente o bem jurídico tutelado. 
De verdade, a gama de possíveis bens jurídicos alçados à primazia neste ínterim, é larga. Veja-se: dignidade da pessoa, defesa do direito do trabalho, luta contra a alienação do ser humano, direito do indivíduo a realizar-se, direito à liberdade do trabalho, direito à igualdade no trato, direito à saúde, etc. (GONZÁLES NAVARRO, 2009). Ou, em termos penais, haveria uma pluriofensividade, afetando direitos fundamentais, direitos trabalhistas, individual, coletivo, etc. (GIMENO NAVARRO, 2011).

Ainda, enfatizando seu caráter pluriofensivo:

[...] el mobbing consiste en infligir un trato degradante menoscabando gravemente la integridad moral, que conecta estrechamente con la dignidad humana, puesto que el trato degradante supone 'realizar acciones con el fin de humillar, deshonrar, hacer despreciar o envilecer a alguien afectando su dignidad humana'. (NAVARRO NIETO, 2007, p. 63).

O Assédio Moral no Trabalho é, afinal, comportamento pluriofensivo que ostenta como propósito objetivado ou aceito pelo assediador a lesão à integridade moral da vítima.

Ademais, ultrapassado este marco, em se atingindo outros bens jurídicos, mister a correlativa sanção penal, ad exemplum, integridade física em lesões corporais. Noutras palavras, se houver dupla agressão, produzindo-se danos a bens jurídicos vários, tais como, integridade física, psíquica, honra, liberdade, etc. tratar-se-á de concurso de delitos, obstando a aplicação do princípio da especialidade.

Importa todavia, realçar que há autores que entendem ser a dignidade humana não um distinto bem jurídico, mas “[...] una síntesis de la totalidad de dimensiones físicas o espirituales específicas de la persona humana". (MUÑOZ SANCHÉZ, 2001 apud LAFONT NICUESA, 2008, p. 102).

Além disso, a Lei Colombiana n. 1.010 de 2006 que versa sobre Assédio Laboral, tida como uma das mais completas do mundo, ostenta outro bem jurídico a ser resguardado, qual seja, buen ambiente laboral, responsabilizando, assim, não apenas o assediador, mas necessariamente o empregador. Veja-se: "El trabajo en condiciones dignas e justas, la libertad, la honra, la salud mental de los trabajadores y empleados, la armonía entre quienes comparten un mismo ámbito laboral y el buen ambiente de trabajo”. (BABUGIA, 2015, p. 63).

Perceba-se que há uma evolução no entendimento de agente contaminante, que pode ser tanto um agente químico quanto um assediador.

No sentido da gravidade do comportamento e, por conseguinte, do bem jurídico envolvido, tem-se os apontamentos de que, de fato, o bem jurídico atingido no Assédio Moral seria a alma, a psique da vítima, a redundar inclusive numa sugestão de mudança de nomenclatura para a terminologia acoso psíquico ou acoso anímico ou acoso 
mental, menos usuais: "La masa de acoso sale a matar y mata. El acoso aquí estudiado, en cambio, deja intacto el cuerpo. Se despreocupa de él. Se dirige contra el alma, hiéndola para doblegarla." (GONZÁLEZ NAVARRO, 2009, p. 60 e 84). Em resumo, pretendese submeter a seu domínio, a alma do outro. Caso não consiga, tenta-se a aniquilação (GONZÁLEZ NAVARRO, 2009).

E daí, "Pero, yo pregunto: ¿matar el alma no es, en definitiva, una forma de muerte también?” (GONZÁLEZ NAVARRO, 2009, p. 159).

Nesta mesma linha, refutando os termos mobbing, e mais ainda, bossing (advindo da palavra boss, chefe), define:

Situación de conflicto derivada del ejercicio ilegítimo de un poder 'conformador' o 'domesticador' que se lleva a cabo, de un modo continuado y sistemático - a veces, también con 'desviación de poder' - por un sujeto activo (acosador) con el propósito de domeñar el alma de un sujeto pasivo (acosado), y que tiene lugar en el seno de una organización a la que ambos pertenecen, hállense o no ligados entre sí por una relación de dependencia; conflicto que puede llegar a ser de tal intensidad que hace extremamente difícil al acosado, cuando no imposible, seguir desempeñando sus funciones. (GONZÁLEZ NAVARRO, 2009, p. 92).

Vale salientar que, há previsão do acosso moral no Código Penal Militar Espanhol, posto que os valores e princípios éticos repudiam tal comportamento, com delitos penais militares associados ao mobbing (arts. 98, 99, 101, 103, 106, 138 e 139) (URRUTIKOETXEA BARRUTIA, 2009, p. 60; PORTUGUÉS JIMÉNEZ, 2011, p. 62).

Na criminalização, mister estudar o núcleo da ação típica - o tipo objetivo - que poder-se-ia partir da noção de trato degradante. Importa pontuar que "trato" parece pressupor uma repetição. Todavia, legislações há que admitem caracterizado o Assédio Moral com um único ato, ad exemplum, Quebéc, Canadá (PORTUGUÉS JIMÉNEZ, 2011, p. 42). Ademais, um único ato pode acarretar uma pluralidade de efeitos mantidos pelo tempo e daí, equiparados àqueles produzidos a partir de atos reiterados.

Importa anotar que para alguns autores, está-se diante de micro-ofensas ou microtraumatismos repetitivos cuja acumulação na vítima, com certa intencionalidade, produz o injusto (URRUTIKOETXEA BARRUTIA, 2009). Observe:

Estamos ante una conducta de 'ejecución fraccionada' como el suministro de veneno a la víctima en dosis pequeñas, pero sucesivas, hasta alcanzar el grado de concentración letal -, ante una conducta suya significación solo puede captarse valorando el contexto relacional entre víctima y autor, y el conjunto de actos u omisiones sucesivas. Acudir a la figura de 'delito continuado' no es aquí procedente porque precisamente es la continuación lo que permite afirmar que 
el 'acoso' constituido por vejaciones leves, puede tener relevancia penal. Por ello, la conducta de 'acoso laboral' u otras análogos como el bullying - se caracterizan por la creación de un determinado clima o situación de presión, que la sitúa más cerca de los delitos permanentes, al menos si el acoso se mantiene durante largo tiempo. (LAFONT NICUESA, 2008, p. 17).

Neste ínterim, faz-se menção à intencionalidade e à duração no Assédio Moral no Trabalho. E, em verdade, tais exigências vêm se suavizando.

Assim, a reiteração deverá ser interpretada em cada caso concreto: “[...] y no resulta imprescindible que quienes acosan lo hagan por una intencionalidad $u$ objetivo, es suficiente los efectos producidos contengan un ataque contra la dignidad de la persona que lo padece o se haya creado un entorno hostil, degradante o humillante". (PORTUGUÉS JIMÉNEZ, 2011, p. 16).

De fato, melhor parece ser a solução que entende que a habitualidade não seria um elemento necessário ao tipo, mas, sim, que serviria para classificar a seriedade, convindo como agravante ou qualificadora (URRUTIKOETXEA BARRUTIA, 2009).

Por conseguinte, no que tange ao tipo subjetivo, cuidar-se-ia de um delito doloso em que há vontade de humilhar (neste ínterim, já apondo discussão a posteriori, qual seja, a existência de elemento subjetivo do tipo). E, além disso, o Assédio Moral independeria do dolo específico consistente em obter a saída da vítima do local de trabalho, cingindo-se, na verdade, na vulneração da integridade moral . Para aqueles que admitem a responsabilização penal da pessoa jurídica, o dolo eventual é de aceitação. (BABUGIA, 2015).

Outra altercação que se faz presente é aquela que toca a questão da consumação/tentativa e a classificação do eventual delito de Assédio Moral no Trabalho como um delito de resultado ou de mera atividade. Veja-se:

[...] el autor no debe conocer que su comportamiento hacia la víctima va a generar una situación objetiva y gravemente intimidatoria, hostil o humillante aunque esa situación debe concurrir para la declaración de hecho delictivo penado por el Código Penal. Sin embargo, es de matizar que en el caso del acoso moral al trabajador la situación de acoso que crea sí que está abarcada por el dolo y, por tanto, se trata de un delito de resultado. (PORTUGUÉS JIMÉNEZ, 2011, p. 48).

Veja-se ainda o que segue, segundo alguns estudiosos:

En un principio, y desde una interpretación mayoritaria se defiende que en la definición del tipo estamos ante la unión de una acción ('trato degradante') y un resultado ('menoscabando grave de la integridad moral'), por lo que en la comprobación judicial deberían verificarse ambos de 
manera consecutiva para que se aprecie el delito contra la integridad moral por particulares. Aún así, existe una cierta controversia sobre como entender este tipo delictivo si como un delito de resultado o de mera actividad. Algunos autores, sin negar la configuración como delito de resultado, no ven en el tipo la unión de una actividad y un resultado, ya que el propio concepto de trato degradante conlleva una caracterización por el resultado lesivo. (URRUTIKOETXEA BARRUTIA, 2009, p. 64-65).

Em tese, o Assédio Moral independeria do resultado - lesão à saúde física/ mental ou deterioração das condições laborais que seriam elementos qualificadores -, bastando a potencial capacidade de produzir dano (LAFONT NICUESA, 2008).

Ainda, de fato, a lesão ao bem jurídico existe a partir do instante em que se identifica o bem jurídico com a dignidade humana, caracterizando, pois, o delito como de resultado: assim, a humilhação do assediado independente de outros danos.

Preconiza-se ser grave a conduta que agride a dignidade e a integridade moral da pessoa ainda que não produza resultado médico algum (LAFONT NICUESA, 2008). E, pois, por consequência deste raciocínio, ignora-se qualquer relevância penal ao consentimento. Neste caso, estar-se-ia a dizer que o assediador conhece tal situação, enquadrando-se, em verdade, numa condição objetiva de punibilidade. (PORTUGUÉS JIMÉNEZ, 2011). Então, o debate centra-se na figura de um crime doloso, de dolo direto com o fim último de acossar.

Em remate: "Si el acto hostigador es objetivamente grave para producir la lesión de la integridad moral siempre será consumado no admitiendo formas imperfectas." (LAFONT NICUESA, 2008, p. 45).

Pontue-se, que não haveria nenhuma marca distinta dos sujeitos passivos e ativos, podendo ser quaisquer indivíduos. Contudo, não se pode olvidar que se está diante de uma relação laboral, daí ser um tipo especial.

Poder-se-ia cogitar de um delito agravado quando o sujeito ativo comete o fato prevalecendo-se da superioridade laboral, mobbing vertical descendente. Não se pode desconsiderar que a especial vulnerabilidade e desamparo do assediado que tem maiores dificuldades em livrar-se da coisificação no acosso vertical não desprestigia a criminalização do acosso horizontal, mormente se pensarmos que, em variados casos, os companheiros tornam a vida do assediado um verdadeiro tormento, em cumplicidade mórbida ao chefe, que dificilmente age só, num acoso colectivo. (MARTÍNEZ GONZÁLEZ, 2011, p. 65).

Não se olvida da omissão pura para chefes e demais companheiros de trabalho. Tal presta-se ao empregador e aos demais empregados. A inatividade do empregador conduz a uma maior impunidade do assediador e a um maior isolamento do 
assediado, com consequências que vão da perda da empregabilidade à morte por suicídio (URRUTIKOETXEA BARRUTIA, 2009).

Neste ponto, surge outra altercação, qual seja, a admissibilidade do hipotético crime de Assédio Moral ser um delito comissivo por omissão, na posição de garante (MARTÍNEZ GONZÁLEZ, 2011, p. 53).

Destarte, o atingimento de outras pessoas pelo Assédio Moral Laboral é indiscutível. Familiares, amigos, conhecidos sofrem indiretamente, sendo terceiros prejudicados (GONZÁLEZ NAVARRO, 2009). Ponto interessantíssimo acode a referência a terceiro prejudicado, sejam familiares ou demais terceiros, inclusive a empresa (sucessivas baixas laborais, invalidez permanente, aposentadoria precoce) ou à Administração Pública por prejuízos ao funcionamento dos serviços (LAFONT NICUESA, 2008).

No que concerne à penologia, interessa-nos cogitar medidas pedagógicas e de real proteção como, por exemplo, proibição de comunicação e privação de residir em determinados locais (PORTUGUÉS JIMÉNEZ, 2011).

Também, é relevante sublinhar a função do Ministério Público ao lado do assediado para, suprindo a hipossuficiência laboral deste, impedir pressões econômicas aptas a barrar quaisquer processos penais.

Não se idealiza a criminalização como solução derradeira para o problema de Assédio Moral Laboral, mesmo porque a ausência da lei penal não obsta sua repressão em sede judicial (ADORNO JÚNIOR, 2009).

Importante realçar que o insuficiente manejo do Direito Penal para coibir o Assédio Moral reside mormente na falta de sensibilização, de consciência social, de crer-se na gravidade das condutas, mais que a ausência de tipicidade específica (LAFONT NICUESA, 2008), além da óbvia dificuldade probatória (BABUGIA, 2015).

\subsubsection{Projetos Legislativos}

Existem inúmeras proposições legislativas que pretendem criminalizar o Assédio Moral Laboral, sendo a última apresentada aos 24 de abril de 2017 (PL n. 7.461/2017), de autoria de Carlos Henrique Gaguim - PTN/TO, objetivando alterar o Código Penal Brasileiro, para acrescer o art. 203-A, a saber:

Assédio moral.

Art. 203-A. Praticar, reiteradamente, contra o trabalhador ato hostil capaz de ofender a sua dignidade e causar-lhe dano físico ou psicológico, prevalecendo-se o agente de sua condição de superior hierárquico ou ascendência inerentes ao exercício de emprego, cargo ou função.

Pena - detenção, de um a dois anos. (grifo nosso) 
Perceba-se que, diante do exposto, parece incorrer o projeto legislativo em equívocos: imposição de um ato necessariamente repetido originado do superior hierárquico. Noutros termos, olvida que pode existir um comportamento omissivo que perpetrado uma única vez tem seus efeitos replicados no tempo advindo de colegas ou inferiores. E tal também caracterizaria, pela melhor literatura, Assédio Moral no Trabalho.

Enfim, dentre as inúmeras proposições legislativas que cuidam do assunto Assédio Moral Laboral, destacam-se: PL n. 5.503/2016 de autoria de Alfredo Nascimento - PR/AM, apresentado em 8/6/2016, com Ementa "Acrescenta dispositivo no DecretoLei n. 2.848, de 7 de dezembro de 1940 - Código Penal para instituir o crime de assédio moral", apensado ao PL n. 4.742/2001; PL n. 3.368/2015 de autoria do Subtenente Gonzaga - PDT/MG, apresentado em 21/10/2015, com Ementa "Introduz art. 146-A no Código Penal Brasileiro - Decreto-Lei n. 2.848, de 7 de dezembro de 1940, dispondo sobre o crime de assédio moral no trabalho", tramitando em conjunto com PL n. 4.742/2001; PL n. 5.887/2001 de autoria de Max Rosenmann - PMDB/PR, apresentado em 11/12/2001 com Ementa "Tipifica o assédio moral, acrescentando artigo ao Código Penal, DecretoLei n. 2.848, de 7 de dezembro de 1940, tramitando em conjunto com PL n. 4.742/2001 e PL n. 4.960/2001 de autoria de Feu Rosa - PSDB/ES, apresentado em 1/8/2001 com Ementa "Altera o Decreto-Lei n. 2.848, de 7 de dezembro de 1940 - Código Penal, para instituir o crime de assédio moral", apensado ao PL n. 4.742/2001.

Todas as proposituras legislativas assemelham-se e, por conseguinte, ostentam assemelhadas atecnias. Sobejam, porém, outras graves falhas: o PL n. 5.503/2016 confunde Assédio Moral com abuso de autoridade; o PL n. 3.368/2015 traz uma infindável criatividade de verbos que, ao contrário do certamente visado, restará por enfraquecer o crime de Assédio Moral e o PL n. 5.887/2001, ao inverso, limita excessivamente os possíveis comportamentos contidos no Assédio Moral.

Há o primeiro Projeto Legislativo a tipificar o Assédio Moral no Trabalho, apresentado em 23 de maio de 2001, de autoria de Marcos de Jesus - PL/PE que visa acrescentar ao Código Penal Brasileiro o art. 146-A, a seguir:

Assédio Moral no Trabalho.

Art. 146-A. Desqualificar reiteradamente, por meio de palavras, gestos ou atitudes, a auto-estima, a segurança ou a imagem do servidor público ou empregado em razão de vínculo hierárquico funcional ou laboral.

Pena: Detenção de 3 (três) meses a um ano e multa. (grifo nosso)

Além de conter a imposição inexata da prática reiterada, oblitera hipóteses menos frequentes de agressões físicas (esbarrões, empurrões) a perfazerem o Assédio 
Moral no Trabalho. Ademais, cuidando-se de uma epidemia que pode acarretar a ruína financeira e até a morte da vítima, o quantum proposto assemelha-se diminuto.

O PL n. 4.960/2001 de autoria de Feu Rosa - PSDB/ES, apresentado em 01/08/2001 com ementa "Altera o Decreto-Lei n. 2.848, de 7 de dezembro de 1940 Código Penal, para instituir o crime de assédio moral" parece, entretanto, ser o mais profícuo para reflexão.

Não se olvidando dos apontamentos pregressos e nada obstante impropriedades derivadas de despiciendas repetições, refoge-se, apesar disso, à rasa similitude das outras escritas legislativas:

Assédio Moral.

Art. 149-A. Humilhar, menosprezar ou tecer comentários irônicos, jocosos ou depreciativos sobre pessoa hierarquicamente subordinada, de forma habitual ou contumaz, ou imputar-lhe, igualmente com contumácia ou habitualidade, encargos sabidamente superiores às suas possibilidades ou alheios às competências ou finalidades de seu cargo, emprego, função, posto, graduação ou qualquer outro conjunto delimitado de atribuições e, responsabilidades.

Pena - detenção, de 1 (um) a 2 (dois) anos:

$\S 1^{\circ} \mathrm{Na}$ mesma pena incorre quem, em relação à pessoa que partilhe do mesmo ambiente de trabalho:

I - ignora-a ou a exclui, evitando dirigir-se a ela diretamente;

II - sonega-lhe informações de forma persistente;

III - espalha rumores maliciosos, depreciativos, humilhantes, jocosos ou irônicos a seu respeito;

IV - usurpa-lhe ideias, projetos ou iniciativas ou nega-lhe a autoria de ideias, projetos ou iniciativas.

$\S 2^{\circ}$ A pena é agravada em até dois terços se da conduta resultar prejuízo moral, físico ou financeiro para o sujeito passivo. (grifo nosso)

O debate, enfim, revela-se essencial, consoante já explanado, a principiar pela mais precisa nomenclatura, bens jurídicos atingidos e pertinente disposição topográfica no Código Penal. Perpassa também questões outras como a habitualidade que, ao reverso de significar elemento do tipo penal, pode, em verdade, atuar como qualificadora em virtude da maior gravidade; a intencionalidade, como implacável exigência de um dolo específico; a superioridade laboral, que ao contrário de ser elemento do tipo penal, poderia incidir como agravante do crime de Assédio Moral Laboral; as consequências penais 
para a inatividade/omissão dos colegas do assediado; penas acessórias de real proteção à vítima, além da penalização do assediador, etc.

Ainda, também há projeto legislativo para tipificar o Assédio Moral no Código Penal Militar: PL n. 5.719/2016, de autoria de Cabo Sabino - PR/CE, apresentado em 05/07/2016 e apensado ao PL n. 2.876/2015; PL n. 4.384/2016, de autoria de Cabo Daciolo - S.PART./RJ, apresentado em 16/02/2016 e apensado ao PL n. 2.876/2015 e por fim, PL n. 2.876/2015, de autoria do Subtenente Gonzaga - PDT/MG, apresentado em 02/09/2015 e aguardando Parecer do Relator na Comissão de Relações Exteriores e de Defesa Nacional (CREDN).

Por outro lado, existem proposições para criação do Dia Nacional de Luta contra o Assédio Moral (PL n. 7.146/2010), para instituição de campanhas publicitárias educativas em Rádio e Televisão (PL n. 1.671/2015), para inserção do Assédio Moral como Ato de Improbidade Administrativa (PL n. 8.178/2014, PL n. 4.544/2016 e PL n. 5.698/2016), para obrigação de custeio de tratamento médico em razão do Assédio Moral (PL n. 4.150/2015), para inclusão do Assédio Moral como situação equiparada a acidente de trabalho (PL n. 7.202/2010), etc.

Vale sublinhar que todas as proposições legislativas a criminalizarem o Assédio Moral do Trabalho estão em vias de votação, considerando-se, como visto acima, o apensamento e tramitação conjunta ao PL n. 4.742/2001, pronto para pauta no Plenário, sendo de urgência uma discussão sobre eventuais deficiências legislativas pena de perderse excelente oportunidade de correto combate efetivo no campo penal.

Conclusão

Objetivou-se pesquisar sobre a prevalência do Assédio Laboral no Serviço Público.

O vocábulo "assédio" tem origem controversa, mas os principais etimólogos creem vir do latim obsidium, cerco, cilada.

Nada obstante poder manifestar-se em diferentes cenários, estamos a tratar, neste ínterim, daquele que se dá em virtude do emprego, cargo ou função.

Destarte, o Assédio Laboral é fenômeno antigo, complexo e devastador.

O Assédio Moral no Trabalho perfaz-se como uma violência psicológica laboral a partir de comportamentos agressivos exercidos geralmente de maneira constante, comprometendo a qualidade de vida da vítima, acarretando mazelas psíquico-emocionais, físicas e sociais com prejuízos outros que atingem, por reflexo, a comunidade.

Enfim, viola a dignidade da vítima.

Leymann principiou os estudos sobre mobbing na Suécia na década de 80, entendendo-o como verdadeiro estupro emocional, que ocorre no local de trabalho, 
cuja consequência tinha-se no abandono laboral e na somatização, podendo alcançar o dramático suicídio.

Depreende-se, contudo, ser um conceito interdisciplinar e multidisciplinar, em construção, que aliás não deve imiscuir-se com outros.

Permeado pela noção de poder, melhor explicando, relação assimétrica de poder, oferta peculiaridades, mormente na Administração Pública que se traduz por um "nicho" de assediadores.

Além do atávico comportamento do assediador, una-se a isto a falha ética na gestão de pessoas e na organização do trabalho que explica, aliás, costumeiro posicionamento de negativa do conflito por parte do empregador ou associação à cruel estigmatização da vítima.

A excessiva burocratização da organização e gestão públicas, a falta de profissionalismo dos chefes, a arbitrariedade na delimitação de tarefas, a permeabilidade à política, a insuficiente transparência, os entraves jurídicos para o tratamento adequado da imediata judicialização e divulgação externa, a ausência de mecanismos de solução, a falta da negociação coletiva no trato de matérias relativas aos direitos fundamentais, o emprego abusivo e criminoso por parte do assediador do poder disciplinar punitivo são apenas algumas peculiaridades que contribuem para a expansão do Assédio Moral no Serviço Público ao lado da constatação de que o chefe não dispõe sobre o vínculo funcional da vítima e, pois, principia o acosso e a humilhação para conseguir livrar-se de outro modo do assediado.

Ademais, não se olvida que hierarquia e disciplina estejam presentes em qualquer forma de organização do trabalho, porém, há um recrudescimento desta principiologia na Administração Pública, o que interfere diretamente no fenômeno do assédio. O domesticar é ambicionado. E o poder disciplinar revela-se como melhor instrumento de humilhação e dominação.

E tal quadro caminha para uma exacerbação à medida que a burocratização bem assim se eleva. Destarte, tem-se como ilação no extremo contexto das Corporações Militares.

Em paralelo a outras nações, pretende-se a criminalização do Assédio Laboral como um das medidas de Política Pública para enfrentamento.

Não se desconsiderando o antecedente Compliance ou Protocolo Antiassédio e as tutelas restitutórias e reparatórias, o Direito Penal faz-se instrumento perfeitamente elogiável para tentar-se erradicar o Assédio Laboral, partindo-se da grandeza do bem jurídico a proteger - dignidade - ao lado das gravíssimas e diversificadas consequências deste fenômeno.

E, principalmente, mesmo que o Assédio Moral independa do resultado - lesão à saúde física/mental ou deterioração das condições laborais, inclusive com 
abandono do local de trabalho, que seriam elementos qualificadores -, basta à vulneração da integridade moral do assediado.

Enfim, existem inúmeras proposições legislativas que pretendem criminalizar o Assédio Laboral, sendo que o primeiro Projeto Legislativo a tipificar o Assédio Moral no Trabalho, apresentado em 23 de maio de 2001, de autoria de Marcos de Jesus - PL/PE, visa acrescentar ao Código Penal Brasileiro o artigo 146-A, a seguir:

Assédio Moral no Trabalho.

Art. 146-A. Desqualificar reiteradamente, por meio de palavras, gestos ou atitudes, a autoestima, a segurança ou a imagem do servidor público ou empregado em razão de vínculo hierárquico funcional ou laboral.

Pena: Detenção de 3 (três) meses a um ano e multa. (grifo nosso)

Além de conter a imposição inexata da prática reiterada - imposição despicienda -, oblitera hipóteses menos frequentes de agressões físicas (esbarrões, empurrões) a perfazerem o Assédio Moral no Trabalho. Ademais, cuidando-se de uma epidemia que pode acarretar a ruína financeira e até a morte da vítima, o quantum proposto assemelha-se diminuto, mormente se houver indigência econômica ou suicídio.

E, vale salientar que, todas as proposituras legislativas assemelham-se e, por conseguinte, ostentam assemelhadas atecnias. Depreende-se que, tais propostas legislativas não se encontram absolutamente alinhadas aos contornos do fenômeno Assédio Moral, e pois, há o risco criar-se um tipo penal incapaz ou ineficiente para a proteção social.

Indispensável, pois, uma cuidadosa tipificação, mormente no Direito Criminal, quando se está diante da tipicidade penal, para obstar que tudo possa ser inserido na ideia de Assédio Moral no Trabalho, e daí, afinal, haja correspectivo enfraquecimento. Uma precária resposta à sociedade não merecerá os postulados do Direito Penal nem a eticidade que o Assédio Moral no Trabalho necessita.

Uma Política Pública de enfrentamento ao Assédio Laboral - resultante de uma falha ética na gestão de pessoal e na estrutura organizacional combinada à degeneração moral de outros - cujo objetivo principal seria divulgar o assunto, a partir da Ética nas relações laborais, estratégias de luta e ações de apoio aos assediados, faz-se imperiosa.

In casu, observar com criticidade a Administração Pública, principiando um olhar e uma discussão entre os próprios servidores e a sociedade é imprescindível para tentar-se erradicar o Assédio Moral no Serviço Público.

Campanhas educativas com o fito da sensibilização atreladas à última responsabilização, inclusive financeira do Estado, são medidas para obstar o quadro inadmissível de uma prática nefasta e prejudicial em meio que possui a obrigação da ética. 
Pesquisas levadas por especialistas que possam detectar ambientes tóxicos e impulsionar o debate sobre ética e democracia são fundamentais.

E, principalmente, ter-se em foco que o Assédio Moral interrompe uma boa prestação do serviço público, fator que aliado à dor das vítimas, impõe profundo exame.

\begin{abstract}
"Só me restam forças para evitar que outras pessoas possam passar pela mesma situação que me fizeram passar. Estou morta em vida, mas estou disposta a extrair energia de onde quer que seja para ajudar outros a saírem do inferno por que eu passei".

Iñaki Piñuel y Zabala
\end{abstract}

São Paulo, 4 de agosto de 2017.

\title{
Referências
}

ADORNO JÚNIOR, Helcio Luiz. Assédio moral no ambiente de trabalho. Universitas, Mogi Mirim, ano 2, n. 3, p. 52-67, jul./dez. 2009. Disponível em: $<$ http://revistauniversitas.inf.br/index. php/UNIVERSITAS/article/viewFile/86/68>.

BABUGIA, Marinés Dolores. La prueba en el acoso laboral. Montevideo: B de F Ltda., 2015.

BRASIL. Ministério da Justiça e da Cidadania. Hierarquia, aspectos da cultura organizacional e implicações na qualidade de vida: um estudo nas polícias militares brasileiras. Coordenação de David Mamblona Marques Romão et al. Brasília: Ministério da Justiça e Cidadania, Secretaria Nacional de Segurança Pública, 2016.

BRASIL. Secretaria Nacional de Segurança Pública. Mulheres nas instituições de segurança pública: estudo técnico nacional. Brasília: Ministério da Justiça, Secretaria Nacional de Segurança Pública (SENASP), 2013.

CONDE COLMENERO, Pilar. El acoso laboral en empleo público. Granada: Comares, 2009.

FABREGAT MONFORT, Gemma. (Directora). Acoso moral, sexual y por razón de sexo en el trabajo: un tratamiento integral. Albacete: Bomarzo, 2012.

FABREGAT MONFORT, Gemma. La obligación empresarial de tutela frente al acoso laboral en la empresa. Albacete: Bomarzo, 2011.

FERREIRA, Aurélio Buarque de Holanda. Novo dicionário da língua portuguesa. 2. ed. Rio de Janeiro: Nova Fronteira, 1986.

GIMENO NAVARRO, Miguel Ángel et al. Protocolos sobre acoso. 2. ed. Valencia: Tirant lo Blanch, 2011. 
GONZÁLEZ NAVARRO, Francisco. La dignidad del hombre y el acoso psíquico en el trabajo que se presta en una administración pública. Navarra: Aranzadi, S. A., 2009.

HARNOIS, Gaston; GABRIEL, Phyllis. Mental health and work: Impact, issues and good practices. Geneva, 2000. Disponível em: <http://www.ilo.org/wcmsp5/groups/public/---ed_emp/---ifp_skills/ documents/publication/wcms_108152.pdf>. Acesso em: 13 jul. 2017.

HIRIGOYEN, Marie-France. El acoso moral en el trabajo: distinguir lo verdadero de lo falso. 1. ed. 2. reimp. Buenos Aires: Paidós, 2008.

HIRIGOYEN, Marie-France. Mal-estar no trabalho: redefinindo o assédio moral. Tradução Rejane Janowitzer. São Paulo: Bertrand do Brasil, 2002.

LAFONT NICUESA, Luis. El delito de acoso moral en el trabajo. Valencia: Tirant lo Blanch, 2008.

LEYMANN, Heinz. Vuxenmobbning: om psykiskt våld i arbetslivet. Stockholm: Studentlitteratur, 1986.

MARTÍNEZ ABASCAL, Vicente Antonio. El acoso moral en el trabajo. Claves para su protección extrajudicial. Valencia: Tirant lo Blanch, 2008.

MARTÍNEZ GONZÁLEZ, María Isabel et al. El acoso: tratamiento penal y procesal. Valencia: Tirant lo Blanch, 2011.

MARTINS, Sergio Pinto. Assédio moral no emprego. 5. ed. São Paulo: Saraiva, 2017.

MOLERO HERMOSILLA, Antonio José. Acoso moral y comunicación interna en la empresa. Madrid: Fragua, 2010.

NASCIMENTO, Sônia Aparecida Costa Mascaro. Assédio moral. São Paulo: Saraiva, 2011.

NAVARRO NIETO, Federico. La tutela jurídica frente al acoso moral laboral. Navarra: Aranzadi, S. A., 2007.

ORGANIZAÇÃO INTERNACIONAL DO TRABALHO. Directrices marco para afrontar la violencia laboral en el sector de la salud. Geneva, 2002. Disponível em: <http:/www.ilo.org/ wcmsp5/groups/public/---ed_dialogue/---sector/documents/publication/wcms_160911.pdf>. Acesso em: 13 jul. 2017.

PIÑUEL Y ZABALA, Iñaki. Mobbing. Como sobreviver ao assédio psicológico no trabalho. São Paulo: Edições Loyola, 2003.

PIÑUEL Y ZABALA, Iñaki. Neomanagement: jefes tóxicos y sus víctimas. Madrid: Aguilar, 2004.

PORTUGUÉS JIMÉNEZ, Vanessa D. Delito de acoso laboral o mobbing. Barcelona: Bosch, 2011.

SOUZA, Edinilsa Ramos de et al. Sofrimento psíquico entre policiais civis: uma análise sob a ótica de gênero. Cad. Saúde Pública, Rio de Janeiro, v. 23, n. 1, p. 105-114, 2007. Disponível em: <http:// www.scielo.br/pdf/csp/v23n1/11.pdf >. Acesso em: 1 de junho de 2017. 
SOUZA, Edinilsa Ramos de; MINAYO, Maria Cecília de Souza. Missão investigar: entre o ideal e a realidade de ser policial. Rio de Janeiro: Garamond, 2003.

URRUTIKOETXEA BARRUTIA, Mikel. Acoso laboral y lesión de derechos fundamentales. Albacete: Bomarzo, 2014.

URRUTIKOETXEA BARRUTIA, Mikel. La vía penal en el tratamiento jurídico del acoso laboral. Albacete: Bomarzo, 2009. 
